\title{
Regionální rozložení přímých zahraničních investic v kontextu ekonomické úrovně krajů České republiky
}

\author{
Milan DAMBORSKÝ
}

\begin{abstract}
Regional distribution of the foreign direct investments in the context of the economic level of the regions of the Czech Republic
\end{abstract}

Abstract: Foreign direct investments (FDIs) are one of the key factors determining the development of the world economy as well as national and regional economies. The paper is focused on the assessment of the distribution of the FDIs in relation to the economic level of the regions. The paper is based on the assumption that the foreign direct investments are beneficial for regional economies. The aim of the paper is to assess whether FDIs contribute to reduction or increase of differences in the economic level of the regions in the Czech Republic. The study verifies the hypothesis: "Foreign direct investments are realized over-proportionally in the regions with a higher economic level and so the differences in the economic level of the regions of the Czech Republic are deepening." The impacts of FDIs on the economic development are assessed in the theoretical part. The theoretical part is oriented on the relations of the FDIs and the labour market, the technology transfer, the domestic firms, export potential and other issues. The hypothesis was tested by the concentration analysis. This analysis confirmed that FDIs were realized over-proportionally in the regions with higher economic level and thus the FDIs were contributing to deepening of the differences in the economic level of the regions. The analysis confirmed over-proportional volume of FDIs in regions with higher gross domestic product and gross value added over the whole reference period from 1999 to 2016 and in the regions with lower unemployment rate in the period from 2009 to 2016.

Keywords: investment, region, economy, development, FDI, Czech Republic

\section{Úvod}

Př́mé zahraniční investice (dále také FDI - podle Foreign Direct Investments) představují jeden z klíčových faktorů determinující vývoj světové ekonomiky i jednotlivých národních a regionálních ekonomik. V souvislosti s globalizací se přímé zahraniční investice a s tím související investiční pobídky stávají stále významnějším faktorem ekonomického vývoje světové a české ekonomiky a jejích regionů, což je výsledkem rostoucího objemu realizovaných investic. Mění se struktura investic a stále větší roli hraje zvláště v českém prostředí reinvestovaný zisk. Mění se charakter investic (klesá podíl zpracovatelského průmyslu) i původ investorů. Na tyto změny bezprostředně reagují také jednotlivé vlády a regionální reprezentace (v případě ČR kraje) v rámci svých hospodářských politik zejména v oblasti investičních pobídek, které jsou součástí hospodářské politiky většiny států světa a více či méně také samosprávných regionů.

Přímé zahraniční investice jsou také faktorem, který determinuje také ekonomický vývoj regionů České republiky. Velmi sledovanou problematikou se regionální rozložení přímých zahraničních investic stalo po roce 2000, kdy vznikly kraje. Ačkoliv je politika investiční podpory (investiční pobídky) v kompetenci zejména centrální vlády (hlavně Ministerstva průmyslu a obchodu ČR a jeho podřizené organizace Agentury pro podporu podnikání a investic

DOI: https://doi.org/10.33542/GC2019-2-01 
- CzechInvest), kraje a města mohou v rámci své samosprávné činnosti aktivně podpořit investiční atraktivnost svých regionů s cílem zvýšit ekonomický růst a rozvoj. Přímé zahraniční investice tak hrají svou významnou úlohu v regionální politice na národní i regionální úrovni a jejich analýza je významným tématem regionálního rozvoje. Výrazné směřování přimých zahraničních investic mimo ekonomicky zaostávající regiony dále prohlubuje ekonomické rozdíly a způsobuje negativní efekty zejména v sociální oblasti.

V návaznosti na výše zmíněné byl zvolen cíl článku, kterým je zhodnotit roli př́mých zahraničních investic ve snižování nebo zvyšování meziregionálních rozdílů v ekonomické úrovni, resp. ověřit hypotézu: „Př́ímé zahraniční investice směřují nadproporcionálně do regionů s vyšší ekonomickou úrovní a tím prohlubují rozdíly v ekonomické úrovni jednotlivých regionů České republiky“. Ta vychází z předpokladu, že pokud FDI pozitivně působí na ekonomický růst regionu (což je v článku doloženo rešerší), vede jejich nadproporcionální zastoupení v regionech s vyšší ekonomickou úrovní k prohloubení regionálních disparit.

\section{Proč jsou přímé zahraniční investice zásadní pro ekonomický vývoj regionu}

Přímé zahraniční investice představují tradiční téma ekonomie a ekonomické geografie nejméně od 70. let 20. století a existuje množství textů, které se vztahují k problematice FDI s větší nebo menší vazbou na problematiku regionálního rozvoje.

$\mathrm{Z}$ rešerší je doložitelný pozitivní dopad přímých zahraničních investic na trh práce, zejména vytváření nových pracovních míst a s tím související snižování nezaměstnanosti, růst mzdové úrovně, vzdělávání a produktivity práce (např. Edfelt 1975 nebo Goncalves 1986, Görg a Greenaway 2004). Nejvíce se tak děje v průmyslu. Dalším pozitivním efektem pro hostitelskou ekonomiku je technologický transfer přispívající k vyšší produktivitě a konkurenceschopnosti ekonomik (např. Kokko 1992, Teece 1977). K tomu Graham a Krugman (1995) uvádí, že domácí firmy mají lepší znalost a přístup na domácí trhy. Pokud se rozhodne zahraniční firma vstoupit na trh, musí využít komparativních výhod (ve srovnání s domácími firmami). FDI se tak stávají hlavním kanálem pro transfer technologií do rozvojových zemí (dále také napřs. Borensztein et al. 1998). Srholec (2004) dále doplňuje, že nejsilnější technologický transfer lze identifikovat u „,market-seeking“ investic v podobě poradenských služeb, logistických či distribučních sítí. Vedle transferu technologií se domácí společnosti mohou od nadnárodních společností naučit, jak exportovat své zboží či služby (např. Wagner 2014). Tito autoři navazují na tradiční Solowův model (Solow 1956), který identifikoval růst produktivity práce v závislosti na množství kapitálu (např. FDI). Platí za podmínky ceteris paribus. Ekonomický růst je dle Solowa funkcí práce, kapitálu a technologie. I když jsou FDI z hlediska technologického rozvoje země považovány za pozitivní, lze nalézt také kritické pohledy. Aitken a Harrison (1999) zjistili, že v případě malých podniků znamenal př́íchod zahraničních investorů (kteří vstoupili do těchto společností) růst produktivity, avšak prríchod zahraničních investorů negativně ovlivnil produktivitu celé domácí ekonomiky. Obdobně také Fallon, Cook (2010) upozorňují, že ačkoliv jsou prrímé zahraniční investice obecně považovány za velmi př́nosné pro rozvoj regionálních ekonomik, výsledky nejsou tak jednoznačné. Vazby FDI a hostitelské země jsou velmi omezené, vedení společnosti je vzdálené, rozhodovací autonomie slabá, regionální firmy jsou v podřízené roli, výroba je často málo sofistikovaná, odbytové cesty podléhají korporátní strategii. Pro celkové zhodnocení dopadů prímých zahraničních investic na národní a regionální ekonomiky má význam výše reinvestovaného zisku. Ta je závislá na životní fázi investice (Vernon 1966, Markusen 1985). Podíl reinvestovaného zisku je nejvyšší v úvodních životních fázích investice, kdy investice zaznamenává velmi výrazný růst.

Přestože existují výzkumy poukazující na negativní dopady FDI, z provedených rešerší vyplývá, že pozitivní hodnocení jednoznačně převládá. FDI jsou považovány za exogenní faktor růstu přispívající k rozvoji hostitelských regionálních ekonomik, zejména těch, které ekonomicky zaostávají. Děje se tak prostřednictvím poptávkové stimulace, růstu zaměstnanosti a mezd a růstu exportního potenciálu. Relevantnost tématu FDI v kontextu prostorového rozložení a regionálního rozvoje je tak významná. 


\section{Co rozhoduje o umístění investice a role pracovní síly}

Rozhodnutí investora o umístění (lokalizaci) investice je pod vlivem různých faktorů determinujících atraktivnost území. Analýza faktorů investiční atraktivnosti stála už u samotného vzniku regionální či prostorové ekonomie. Investiční atraktivnost území fakticky představuje transformovaný pohled na teorii lokalizace (Capello et al. 2007). Každé místo disponuje určitými zdroji a každý investor volí místo dle svého charakteru (svých potřeb) a charakteru investice. Tyto zdroje i potřeby se v čase mění, a proto dochází ke změně umístění ekonomických aktivit.

První ucelenou lokalizační teorii vytvořil J. H. von Thünen (1826). Teorie se zaměřila na zemědělskou výrobu a byla založena na předpokladech dokonalé konkurence. Na tuto teorii bezprostředně navázal teorií lokalizací průmyslu A. Weber (Weber 1969). Další teorie představovaly modifikované lokalizační koncepty, zejména lokalizační teorie služeb, polarizační teorie založené na podmínkách nedokonalé konkurence, např. Lösch (1954), Christaller (1966), Maier a Tödtling (1997). Modifikace s sebou prrináší také strukturalistický př́stup k hodnocení ekonomiky. Kromě tradičního sektorového hodnocení ekonomiky dle podílu jednotlivých sektorů se objevily sofistikovanější pohledy na problematiku hodnocení investiční atraktivnosti. Do popředí zájmu se dostává chování nadnárodních korporací, viz např̀. Vernon (1966) nebo Markusen (1985). Tyto teorie zdůrazňují význam velkých korporací, které prostřednictvím přímých zahraničních investic ovlivňují národní i regionální ekonomiky.

Pro pochopení měkkých lokalizačních faktorů mají zásadní význam institucionalismus a jemu blízké behaviorální př́stupy, viz např. Galbraith (1985), Berle, Means (1932) a další.

Od 90. let 20. století se teoretický přístup $\mathrm{k}$ investiční atraktivnosti vyznačuje značnou heterogenitou. Otázku velikosti trhů jako předpokladu realizaci úspor z rozsahu řešil Paul Krugman (Krugman, Venables 1995). Významným tématem se stávají otázky koncentrace investic. Ty jsou rozpracovány v koncepci navazující na teorii klastrů (např. Rychen, Zimmermann 2008, Phelps 2008, Grote, Taeube 2006, Baldwin et al. 2008), které určují koncentraci jako prrirozený jev v ekonomice. Kromě faktorů působících směrem ke koncentraci investic, působí také faktory směrem k dekoncentraci. Fujita et al. (1999) uvádí tři koncentrační faktory, kterými jsou dodavatelsko-odběratelské vazby, silný trh, difuse znalostí, a dva faktory dekoncentrační, tj. imobilita faktorů a koncentrační náklady, např. složitější koordinace (také např. Pelegrin, Bolancé 2008). Dekoncentrační procesy jsou podpořeny možnostmi, které poskytují informační a komunikační technologie.

V tržním hospodářství tak působí protisměrně lokalizační faktory vedoucí ke koncentraci investic do ekonomicky vyspělejších regionů s nižší nezaměstnaností (jsou to multiplikační efekty generující polarizaci ekonomiky, úspory z rozsahu dané velikostí trhu a další) a tendence opačné, vyvolané zejména možností úspor nákladů (např. Vernon 1966, Markusen 1985, Fujita et al. 1999) např. nižší cenou práce. Dekoncentrační tendence (směřování do ekonomicky slabších regionů) v drtivé většině dále podporují jednotlivé národní vlády zvýhodněním ekonomicky zaostávajících regionů $\mathrm{v}$ rámci investiční podpory prŕmých investic, tj. regionalizací investičních pobídek. Jejich vliv je však velmi omezený (zejména sektorově), lze tedy předpokládat, že hypotéza bude potvrzena a přímé zahraniční investice směřují nadproporcionálně do regionů s vyšší ekonomickou úrovní a tím prohlubují rozdíly v ekonomické úrovni jednotlivých regionů České republiky.

\section{FDI a jejich hodnocení v kontextu regionálního rozvoje v ČR a střední Evropy}

Přímé zahraniční investice jsou vnímány jako klíčový prvek národních i regionálních ekonomik. Specificky roli FDI ve středoevropském prostoru řešily např. Fifeková, Nemcová (2015). K problematice FDI uvádí, že jsou jedním z klíčových faktorů rozvoje zemí V4. Ačkoliv je hodnocení poměrně obtížné, lze identifikovat prrínos pro zrychlení strukturální adaptace a technologické výkonosti v zemích V4.

Komplexní hodnocení role FDI v kontextu střední Evropy provedl Pavlínek (2009). Zhodnotil efekty př́mých zahraničních investic na místní a regionální rozvoj v CEE regionu, vč. regionální nerovnosti na subnárodní úrovni (dopady na regionální rozvoj). Uvádí, že FDI jsou obecně 
typické koncentrací v prostoru a nerovnoměrným na všech úrovních od globální, přes mezinárodní, národní až po regionální. FDI jsou koncentrovány do ekonomických klastrů, kde mohou být získány externí úspory z rozsahu dané velikostí trhu, zdroji trhu práce, produkčními faktory, dodavately, infrastrukturou, institucemi a inovační kapacitou. Proto více vyspělé a více industrializované regiony přitahují větší objem investic než regiony méně rozvinuté a méně industrializované (od roku 1990). FDI tak přispívají k nerovnoměrnému rozvoji a regionální polarizaci v CEE regionu. Historicky jde nejvíce investic do hlavních měst, které jsou obvykle také městy největšími, a do dalších velkých městských oblastí. Směřují sem zejména investice v oblasti bankovnictví, finančních služeb a služeb souvisejících s obchodem. Bratislava, Budapešt', Lublaň, Praha, Tallin, Riga a Vilnius jsou toho př́íkladem. Pavlínek (2009) dále uvádí, že FDI jsou značně heterogenní. To zapříčiňuje také značnou variabilitu efektů, které FDI přináší. Dále je třeba respektovat rozdíl v krátkodobých, střednědobých a dlouhodobých efektech. FDI mají pozitivní i negativní efekty pro regionální rozvoj. Není však překvapující, že FDI v CEE regionu přispívají k existující úrovni regionální nerovnováhy a polarizaci a to nejen v porovnání hlavních měst a periferních regionů, ale také z pohledu vytvářené přidané hodnoty.

Pavlínek (2018) řešil dále FDI v kontextu slovenského automobilového průmyslu. Výsledky vychází z analýzy 133 firem automobilového průmyslu a 50 řízených rozhovorů realizovaných v letech 2011 až 2015. Empirická analýza odhalila slabé a závislé dodavatelské vazby mezi zahraničními dceřinými společnostmi a domácími firmami, které omezují potenciál pro technologický transfer. Studie dále potvrdila pozitivní dlouhodobý efekt FDI v automobilovém průmyslu pro rozvoj regionu.

Investice ve střední Evropě analyzují také Hlaváček, Beata (2016), kteří tyto investice hodnotí v kontextu transitivity ekonomik. Autoři v této souvislosti uvádí, že projevy investic jsou různé jak v čase, tak prostoru. Při určitém nasycení mohou být investice až zdroje ekonomické krize, avšak stále platí, že zahraniční investice jsou nezbytné pro růst konkurenceschopnosti regionů ve střední Evropě. Podobně jako Sucháček (2013), autoři potvrzují, že mezi regiony tak dochází k určité soutěži v lokalizaci investic. FDI na jedné straně reagují na rozvojový potenciál regionu, ale zároveň jej také tvoří (viz také např. Viturka 2018).

Často řešeným tématem je problematika vlivu FDI na domácí firmy. Obecně platí, že lokalizace aktivit s vyšší přidanou hodnotou má větší potenciál pro rozvoj regionů než aktivit s nízkou přidanou hodnotou. Předpokladem takových investic je však jejich vysoká přidaná hodnota. V kontextu ČR Jarolím (2000) zamítnul hypotézu, že zahraniční účast má pozitivní efekt na růst produktivity práce domácích firem. Hypotéza pozitivních vedlejších efektů byla označena jako statisticky nevýznamná. Podobně také Konings (2001) nenašel žádnou vazbu mezi pozitivními vedlejšími efekty mezi FDI a domácími firmami v Bulharsku, Rumunsku a Polsku. V Rumunsku a Bulharsku dokonce našel negativní vedlejší efekty pro domácí firmy. V př́ípadě Polska nebyly identifikovány žádné vedlejší efekty.

Mezi ekonomy v České republice jsou př́mé zahraniční investice všeobecně považovány za jeden z klíčových prvků determinující pozitivní ekonomický vývoj od počátku transformace v roce 1990 (např́klad Zamrazilová 2007 nebo Benáček 1999). Na pozitivní roli FDI v ekonomice z hlediska technologie upozorn̆uje z českých autorů Srholec (2004). Naopak v kontextu investičních pobídek je role prímých zahraničních investic často hodnocena velmi kriticky (viz např. Schwarz a kol. 2007). Další autoři se zaměřují na přímé zahraniční investice jako na klíčový prvek socioekonomického vývoje regionů ČR. Komplexní pohled na tuto problematiku poskytují Wokoun a kol. (2010). Na problematiku př́mých zahraničních investic je pohlíženo z různých perspektiv regionálního rozvoje. Analýza založená na kvantifikovaném výzkumu je zde však provedena velmi omezeně.

Přímo na regionální rozložení FDI v ČR se zaměřují další články (kromě výše zmíněného Pavlínek 2009). Damborský a Ř́hová (2008) srovnávají socioekonomickou úroveň jednotlivých krajů a př́liv FDI s cílem zjistit, ve kterých krajích ČR přímé zahraniční investice přispívají k nárůstu regionálních rozdílů, a kde je tomu naopak. Primárně využívají metodu srovnání pořadí krajů. Autoři konstatují, že vliv prímých zahraničních investic na meziregionální rozdíly 
je nejednoznačný, v případě regionů Hl. m. Praha, Středočeský, Královéhradecký, Zlínský, Karlovarský, Olomoucký a Ústecký kraj přispívá př́iliv přímých zahraničních investic ke zvýšení regionálních disparit. $\mathrm{V}$ př́padě regionů Jihočeský, Plzeňský a Moravskoslezský kraj přispívá př́liv př́mých zahraničních investic ke snížení regionálních disparit a v případě regionů Liberecký, Pardubický, Jihomoravský kraj a kraj Vysočina nelze jednoznačně na základě porovnání pozice dle př́livu př́mých zahraničních investic a pozice dle socioekonomické úrovně určit, zda díky př́livu FDI dochází spiše ke snížení nebo zvýšení regionálních rozdílů v ČR. Zdražil a Hýblová (2013) se zaměřují na posouzení vlivu přímých zahraničních investic na tvorbu regionálního HDP a zaměstnanost, a současně porovnání intenzity vývoje přímých zahraničních investic a zmíněných ukazatelů. Provedenou analýzou byly zjištěny značné disproporce v rozložení př́mých zahraničních investic mezi sledovanými regiony, a to jak vzhledem $\mathrm{k}$ stavu, tak k vývoji. Dále bylo zjištěno, že zatímco vliv FDI na tvorbu regionálního HDP je značný, k problematice zaměstnanosti se jeví spíše jako irelevantní. Analýza se primárně zaměřovala na zjištění kauzality mezi FDI a hrubým domácím produktem a nezaměstnaností.

Specificky na vybrané regiony ČR se zaměřila Chobotová (2014). Cílem jejího článku je analyzovat dopad přimých zahraničních investic (FDI) na rozvoj vybraných regionů. Zvolenými regiony jsou Moravskoslezský a Zlínský kraj. Pro zhodnocení dopadu prímých zahraničních investic byl použit koeficient korelace, pomocí kterého byla zkoumána vzájemná závislost mezi prŕlivem FDI a výší regionálního HDP, FDI a mírou nezaměstnanosti, a mezi FDI a počtem ekonomických subjektů. Na základě provedených analýz byly zjištěny rozdíly mezi sledovanými regiony ve vývoji přímých zahraničních investic za sledované období. Z korelační analýzy byl potvrzen vliv FDI na tvorbu regionálního HDP, který je významný. Vztah k problematice nezaměstnanosti a počtu ekonomických subjektů se prokazuje jako nepodstatný.

V kontextu všech výše uvedených informací je zřejmé, že ekonomická úroveň regionu a př́liv FDI jsou ve vzájemné interakci. Ekonomický rủst přispívá k vyšší atraktivitě regionu pro zahraniční investice a FDI přináší nové impulsy k ekonomickému růstu. Neplatí to však absolutně. Protisměrné tendence lze identifikovat zejména na trhu práce.

\section{Metodologie}

Článek se nejprve ve své teoretické části zaměřuje na zhodnocení významu př́mých zahraničních investic v ekonomice a na problematiku lokalizace dle již publikovaných textů.

$\mathrm{Na}$ popsanou metodologii navazuje koncentrační analýza př́mých zahraničních investic v České republice, která poskytuje srovnání založené na relativizaci a standardizaci dat za využití ukazatelů:

(1) index lokalizace: $L_{j}=\frac{P_{j}}{S_{j}}$, kde

$P_{j}$ je podíl j-tého kraje na objemu př́mých zahraničních investic v ČR,

$S_{j}$ je podíl j-tého kraje na celkovém počtu zaměstnanců ČR.

Tento index ukazuje, zda je daný jev (v tomto př́ípadě FDI) v daném regionu zastoupen nadproporcionálně (pro $L_{j}>1$ ), podproporcionálně (pro $L_{j}<1$ ) nebo proporcionálně (pro $L_{j}=$ 1) vzhledem k počtu zaměstnancủ. Právě počet zaměstnanců v tomto př́ipadě reprezentuje potenciál pro realizaci FDI. Často je alternativně volen počet obyvatel, kde je však zahrnuta také poproduktivní a předproduktivní složka, např. důchodci nebo studenti.

(2) koeficient lokalizace: $K L=\sum_{1}^{j}$ Kladných $\left(P_{j}-S_{j}\right)$,

který dokládá (ne)rovnoměrnost $\mathrm{v}$ rozmístění př́mých zahraničních investic dle podílu zaměstnanců. $\mathrm{KL}=0$ znamená, že prímé zahraniční investice jsou rozmístěné přímo úměrně dle podílu zaměstnanců, $\mathrm{KL}=1$ je nereálná hodnota, která znamená, že region bez jediného zaměstnance se podílí na přímých zahraničních investicích 100 procenty. 
Index lokalizace byl za využití korelačních koeficientů porovnán s územním rozložením hrubého domácího produktu, hrubou přidanou hodnotou a mírou nezaměstnanosti. Hrubý domácí produkt představuje klasický ukazatel pro hodnocení ekonomické síly i úrovně regionu. Hrubá přidaná hodnota je ukazatel, který je velmi vhodný pro hodnocení síly a úrovně podnikatelského sektoru a míra nezaměstnanosti v sobě kombinuje vedle ekonomické dimenze také dimenzi sociální.

Pro analýzu byla zvolena územní úroveň krajů. Tato územní úroveň byla zvolena zejména s ohledem na skutečnost, že kraje v ČR jsou vymezeny na bázi nodálnosti a nerivalidnosti měst (v krajích nejsou dvě srovnatelně významná města) a v tomto ohledu je vliv FDI do ekonomik blízkých regionů omezený, např. s ohledem na řešení veřejné dopravy, kdy spoje primárně směřují do krajského centra či dalších center uvnitř kraje. Výjimku z pohledu nodálnosti tvoří kraj Vysočina, kde v době vzniku krajů byl význam krajského města Jihlava nižší, než bylo v jiných krajích. To se však postupně změnilo a město Jihlava postupně získalo podobné postavení v regionální ekonomice jako ostatní krajská města. Další možné územní jednotky nejsou vhodné. V př́padě okresů řada investic svým vlivem výrazně přesahuje hranice regionu, např. investice automobilek. Regiony soudržnosti (NUTS II) nejsou vhodné a to zejména s ohledem, že se fakticky jedná pouze o statistickou jednotku jednoho až tří samosprávných regionů.

Sledované období 1999 až 2015 bylo zvoleno s ohledem na dostupnost dat. Rok 2015 představuje poslední rok, kdy Česká národní banka zveřejnila data v regionálním členění. Vyšší aktuálnosti tak nelze dosáhnout. Rok 1999 byl zvolen s ohledem na skutečnosti, že se jedná o poslední hodnotu před vznikem krajů a není tak ovlivněna aktivita krajské samosprávy. Tato hodnota je tedy „nultou“ hodnotou. Statistická data byla získána z oficiálních zdrojů České národní banky, Českého statistického úřadu a portálu zaměstnanosti Ministerstva práce a sociálních věcí ČR. Zvolené metody kombinují kvantitativní př́stup s doplněnými normativními soudy vycházející z expertního posouzení a zkušenosti.

\section{Analýza a její výsledky}

FDI v 90. letech 20. století představovaly klíčový nástroj ekonomické transformace. Byla to právě privatizace do zahraničního vlastnictví, která zvyšovala ekonomický (zejména exportní) potenciál ekonomiky. Asi nejúspěšnějším projektem byla investice společnosti Volkswagen AG do Škoda Auto, a.s. Ačkoliv lze FDI označit za klíčové zejména v transitivní fázi ekonomiky, pozitivně působí také dnes. Jsou přirozeným nástrojem kontinuální restrukturalizace ekonomiky, a proto jsou jedním ze sledovaných ekonomických faktorů.

Stav př́mých zahraničních investic v ČR ve sledovaném období 1999 až 2016 kontinuálně rostl. Výjimku tvoři pouze roky 2003 a 2011. Průměrný růst dosáhl 141 mld. Kč nominálně a 124 mld. Kč ve stálých cenách roku 2015. K 31. 12. 2016 dosahovala hodnota FDI 3,124 bil. Kč.

Z hlediska struktury se trvale zvyšuje podíl reinvestovaného zisku. Pouze mezi lety 2014 a 2016 podíl reinvestovaného zisku klesl o 1 procentní bod. Zvyšujícím se podílem reinvestovaného zisku se ekonomika ČR řadí mezi tradiční vyspělé ekonomiky. Podíl reinvestovaného zisku je také indikátorem spokojenosti investorů v ČR.

Z hlediska sektorové struktury dominuje sektor služeb (59,9\%), z toho finanční a pojišstovací činnosti (cca 27 \%). Nejvýznamnějším oborem je zpracovatelský průmysl s 31,6 \%, což potvrzuje fakt, že ČR je tradiční průmyslovou zemí.

Ačkoliv je Česká republika z hlediska ekonomické úrovně regionů poměrně homogenní (s přirozenou výjimkou zvláštního postavení regionu hlavního města), rozložení přímých zahraničních investic je nerovnoměrné. Mezi regiony jednoznačně dominuje Hlavní město Praha, které je přirozeným centrem služeb, včetně bankovních a finančních institucí. Hlavní město Praha dominuje nejen dle absolutních hodnot, ale také dle přepočtu na zaměstnance a obyvatele. Všechny ostatní kraje jsou podprůměrné. Průměru České republiky se blíží pouze Středočeský kraj. Konkrétní data viz Tab. 1. 
Tab. 1. Objem investic celkem (v mld. Kč), objem investic na obyvatele (v tis. Kč) a objem investic na zaměstnance (v tis. Kč) dle krajů ČR, 1999 až 2016 dle stavu investic $k$ 31. 12.2016

\begin{tabular}{|l|c|c|c|c|c|c|c|c|c|c|c|c|c|c|}
\hline Kraj & PHA & STČ & JHČ & PLK & KVK & ULK & LBK & HKK & PAK & VYS & JMK & OLK & ZLK & MSK \\
\hline $\begin{array}{l}\text { Objem investic celkem } \\
\text { (v mld. Kč) }\end{array}$ & 1656 & 311 & 92 & 99 & 22 & 75 & 50 & 58 & 38 & 56 & 130 & 45 & 60 & 203 \\
\hline $\begin{array}{l}\text { Objem investic na obyva- } \\
\text { tele (v tis. Kč) }\end{array}$ & 1435 & 220 & 159 & 169 & 88 & 101 & 130 & 106 & 86 & 117 & 131 & 77 & 114 & 171 \\
\hline $\begin{array}{l}\text { Objem investic na za- } \\
\text { městnance (v tis. Kč) }\end{array}$ & 2437 & 365 & 383 & 393 & 215 & 270 & 326 & 259 & 202 & 280 & 306 & 186 & 269 & 415 \\
\hline
\end{tabular}

Zdroj: Vlastní zpracováni dle dat ČNB (2019); Vysvětlivky: PHA - Hlavní město Praha, STČ - Středočeský kraj, JHČ -Jihočeský kraj, PLK-Plzeňský kraj, KVK-Karlovarský kraj, ULK - Ústecký kraj, LBK - Liberecký kraj, HKK - Královéhradecký kraj, PAK-Pardubický kraj, VYS - Vysočina, JMK - Jihomoravský kraj, OLK - Olomoucký kraj, ZLK - Zlinský kraj, MSK - Moravskoslezský kraj

$\mathrm{V}$ rámci meziročních změn objemu přímých zahraničních investic došlo ve sledovaném období 2000 až 2016 k poklesu objemu investic pouze v letech 2003 a 2011 (fakticky se jedná o stagnaci). V rámci krajů zaznamenal nejvyšší meziroční pokles objem investic Jihomoravský kraj v roce 2005 . Nejvyšší nárůsty byly $\mathrm{v}$ roce 2000 . To je dáno nízkým výchozím objemem investic. Konkrétní data viz Tab. 2.

Tab. 2. Meziroční změny v objemu př́mých zahraničních investic dle krajů ČR, 1999 až 2016 dle stavu investic $k 31.12$, v procentech

\begin{tabular}{|l|r|r|r|r|r|r|r|r|r|r|r|r|r|r|r|}
\hline & ČR & PHA & STČ & JHČ & PLK & KVK & ULK & LBK & KHK & PAK & VYS & JMK & OLK & ZLK & MSK \\
\hline 2000 & 30 & 28 & 32 & 32 & 26 & -18 & 17 & 21 & 37 & 4 & 115 & 35 & 10 & 290 & 47 \\
\hline 2001 & 20 & 24 & 8 & 13 & 18 & 6 & 14 & 13 & 16 & 24 & 68 & 14 & 36 & 30 & 6 \\
\hline 2002 & 19 & 26 & 10 & 9 & 28 & 33 & 10 & 26 & 16 & -3 & -24 & 1 & 9 & 17 & 31 \\
\hline 2003 & 0 & -12 & 17 & -14 & -1 & -6 & -11 & 29 & 6 & 48 & 73 & 19 & 16 & -9 & 38 \\
\hline 2004 & 10 & 11 & -5 & 26 & -5 & 12 & 12 & 51 & 6 & -13 & 5 & 29 & 9 & 3 & 16 \\
\hline 2005 & 16 & 34 & 24 & 37 & 3 & 4 & -18 & 6 & -5 & 4 & 5 & -35 & -17 & 2 & 8 \\
\hline 2006 & 12 & 11 & 15 & 6 & 9 & 2 & -2 & 2 & -12 & 6 & 45 & 19 & -5 & 0 & 38 \\
\hline 2007 & 22 & 18 & 26 & 17 & 11 & 10 & 73 & 12 & 39 & 6 & 25 & 19 & 2 & 24 & 34 \\
\hline 2008 & 8 & 11 & 0 & 12 & 2 & 12 & -1 & 15 & 5 & 16 & -16 & 18 & 19 & 4 & -1 \\
\hline 2009 & 6 & 1 & 18 & 5 & 18 & 11 & 0 & -4 & 15 & -15 & 9 & 35 & 4 & 3 & 6 \\
\hline 2010 & 4 & 6 & -10 & 2 & 5 & -5 & 0 & 7 & 35 & 42 & -10 & 17 & -9 & 23 & -3 \\
\hline 2011 & 0 & 0 & 3 & 5 & -1 & -6 & -16 & -6 & -2 & -6 & -5 & 2 & 2 & 3 & 3 \\
\hline 2012 & 8 & 10 & 19 & -1 & -2 & -20 & -4 & 5 & 14 & -6 & 1 & 5 & 4 & -1 & 8 \\
\hline 2013 & 3 & 3 & 7 & 2 & -6 & 25 & 8 & 3 & -4 & -29 & 0 & 10 & 7 & 5 & -4 \\
\hline 2014 & 4 & 6 & 2 & 2 & 33 & 10 & -8 & -6 & 2 & 15 & 3 & -15 & 14 & 7 & 6 \\
\hline 2015 & 4 & 10 & -6 & 1 & 9 & 0 & -10 & -15 & 8 & -6 & 7 & -17 & 13 & 10 & 7 \\
\hline 2016 & 8 & 10 & -6 & 10 & -2 & 20 & 11 & 14 & 1 & 17 & 6 & 18 & 9 & 11 & 2 \\
\hline
\end{tabular}

Zdroj: Vlastní propočet dle dat ČNB (2019); Vysvětlivky: viz tab. 1

\section{Koncentrační analýza}

Pro koncentrační analýzu byl vyřazen region Hlavní město Praha a to s ohledem na jeho specifické postavení, které by znehodnotilo závěry analýzy. Hlavní město Praha je sídlem řady firem s celorepublikovou působností (např. z bankovního sektoru). Jeho statistiky jsou tak významně zkreslené.

Nejobecnější informaci o nerovnoměrnosti v rozložení přimých zahraničních investic v krajích ČR dokládá koeficient lokalizace. Tento koeficient se pohybuje ve sledovaném 
období 1999 až 2016 mezi hodnotou 0,21 a 0,11. Vývoj tohoto ukazatele má tvar „w“ a nelze přesně určit relevantní trend (viz Obr. 1).

K vyššímu koeficientu lokalizace přispívají regiony s indexem lokalizace, který se odchyluje od průměru. Vysoce nad průměrem se pohybuje Středočeský kraj. Nejvyšší hodnoty indexu lokalizace dosáhl v roce $2014(1,99)$. Nejnižší v roce $2004(1,49)$. Středočeský kraj je velmi atraktivní díky svému napojení na hlavní ekonomický pól ČR Hlavní město Praha. Ve Středočeském kraji jsou lokalizovány klíčové průmyslové investice. Jsou to např́íklad Škoda Auto v Mladé Boleslavi nebo TPCA v Kolíně.

Ve sledovaném období 1999 až 2016 se nad hodnotou 1,0 trvale nepohyboval žádný další kraj. Jihočeský kraj se nad touto hodnotou pohybuje od roku 2005. Ačkoliv tento kraj je možno zařadit mezi ekonomiky nadprůměrné zejména $\mathrm{v}$ oblasti trhu práce, $\mathrm{z}$ hlediska investiční atraktivnosti se drží kolem střední hodnoty. Mezi slabé stránky z hlediska investiční atraktivnosti tohoto kraje patři zejména nevyhovující dopravní infastruktura. Chybí zejména dálniční napojení na Prahu a geograficky blízké Rakousko.

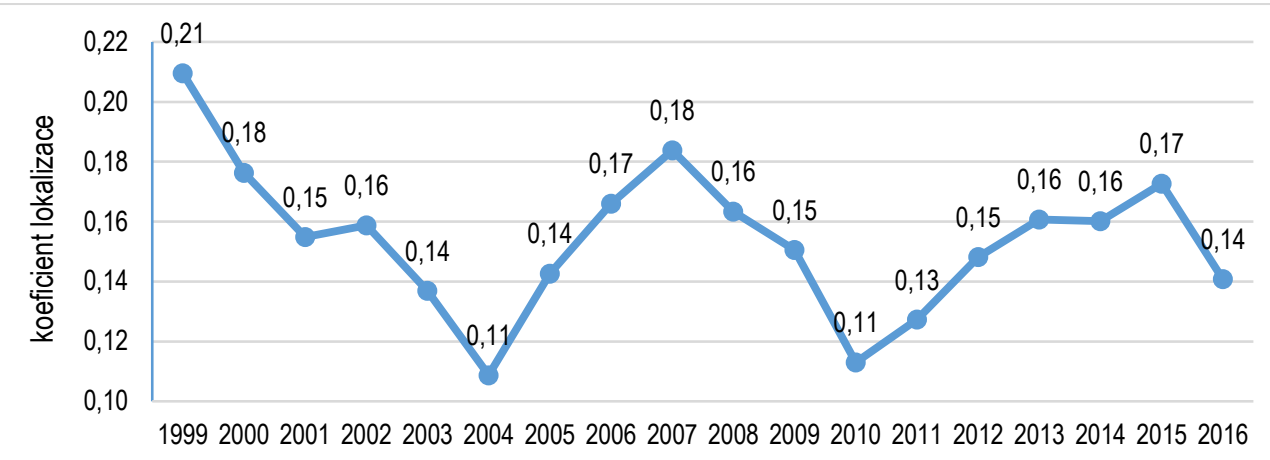

Obr. 1. Vývoj koeficientu lokalizace př́mých zahraničních investic, krajská úroveñ; Zdroj: Vlastni zpracováni a propočty dle dat ČNB (2019) a ČSÚ (2019)

Neurčitý vývoj lze identifikovat v př́ípadě Plzeňského kraje. V období 1999 až 2003 dosahoval tento kraj velmi příznivých hodnot. V roce 2002 převyšoval střední hodnotu indexu o $37 \%$. Následně se tento kraj spíše propadal až do roku 2014. Pozitivní vývoj potvrdil také rok 2015, ale v roce 2016 došlo opět k poklesu. Investiční atraktivnost Plzeňského kraje determinuje zejména samotná metropole Plzeň a dále rozvojová osa Praha - Plzeň - Německo. Silnou stránkou kraje je kvalifikovaná pracovní síla (navazuje na tradici Škody Plzeň), která přilákala zejména průmyslové investice z Německa, Japonska a dalších technologicky vyspělých zemí. Avšak pracovní síla je aktuálně klíčovým limitujícím faktorem dalších investic a její nedostatek je částečně řešen př́íchodem agenturních zaměstnanců ze zahraničí.

Velmi nepř́znivý vývoj shodně vykazují Karlovarský kraj a Ústecký kraj, které spolu tvoří NUTS 2 Severozápad. Zatímco Karlovarský kraj vykazoval nadprůměrnou hodnotu pouze v roce 1999, Ústecký kraj se postupně propadá z druhé nejvyšší hodnoty v roce 1999, kdy převyšoval střední hodnotu o $90 \%$, až na nejnižší hodnotu 0,73 v roce 2015 .

Oba kraje shodně spojují nedořešené strukturální problémy regionální ekonomiky. Problém představuje vzdělanostní struktura se zastoupením málo kvalifikované pracovní síly. Strukturální problémy regionu se zde projevují již od poloviny 90 . let, kdy došlo k útlumu v těžebním průmyslu a navazujících odvětvích. Velkým problémem Karlovarského kraje je dopravní napojení (chybí úplné dálniční napojení na hlavní město) a málo zastoupené terciální vzdělávání.

Liberecký kraj dosáhl nejvyšších hodnot indexu lokalizace v letech 2004 až 2008. Právě v tomto období byl Liberecký kraj po vzoru asijských ekonomik považován za ekonomického „tygra“ mezi kraji ČR. Od roku 2009 až do 2015 hodnota tohoto indexu klesala. Liberecký kraj je velmi atraktivní pro automobilový průmysl, zejména Tier 2, který navazuje na geograficky 
blízkou produkci společnosti Škoda Auto v Mladé Boleslavi. Rozvoj průmyslu je aktivně podporován městem Liberec, které vytvořilo $\mathrm{v}$ městě několik průmyslových zón.

Obdobný vývoj jako Liberecký kraj vykazuje kraj Vysočina. V roce 1999 vykazoval druhou nejnižší hodnotu indexu lokalizace. Nejvyšších hodnot dosahoval tento kraj v letech 2006 a 2007 , kdy byl označován za jednoho z ,tygrư““ mezi regiony ČR. Pozitivní trend se však v následujících letech nepotvrdil.

Pozitivní trend lze zaznamenat v př́ípadě Královéhradeckého kraje. V roce 1999 zde dosahoval index lokalizace 0,59 a postupně rostl až na hodnotu 0,76 v roce 2016 . Tento trend je dále podporován rozšiřujícími aktivitami společnosti Škoda Auto, a.s. v Kvasinách generující další dodavatelské společnosti. Opačný trend lze identifikovat v geograficky nejbližším regionu Pardubický kraj, ve kterém došlo ve sledovaném období k poklesu indexu lokalizace z 1,15 na 0,59.

Relativně stabilní hodnotu indexu lokalizace vykazuje Jihomoravský kraj. Nejnižší hodnoty dosahoval tento kraj v letech 2005 až 2008, tj. v období před ekonomickým poklesem. V následujícím období se projevila stabilita tohoto regionu, resp. vyšší rezistence vůči negativnímu globálnímu trendu.

Mezi regiony vykazující trvale podprůměrné hodnoty indexu lokalizace patří Olomoucký a Zlínský kraj (spolu NUTS II Střední Morava). Olomoucký kraj se dlouhodobě pohybuje v podproporcionálním zastoupení investic a v posledním sledovaném roce 2015 dosáhl druhé nejnižší hodnoty. O něco málo lepší hodnoty vykazuje Zlínský kraj, který s výjimkou příznivých let 2000 až 2002 spíše stagnuje.

Jednoznačně nejpozitivnější trend z hlediska př́livu přímých zahraničních investic vykazuje Moravskoslezský kraj. Zatímco v roce 1999 vykazoval hodnotu indexu pouze 0,59, kontinuálním růstem dosáhl hodnoty 1,30 (v roce 2015). V tomto kraji bylo realizováno několik významných investic. Mezi nimi je asi nejvýznamnější Hyundai Motor Czech, s. r. o. Přesná data viz Tab. 3.

Tab. 3. Vývoj indexu lokalizace prímých zahraničních investic dle krajů ČR, 1999 až 2016 dle stavu investic $k$ 31. 12. a počtu zaměstnancù

\begin{tabular}{|l|r|r|r|r|r|r|r|r|r|r|r|r|r|}
\hline & STČ & JHČ & PLK & KVK & ÚSK & LBK & KHK & PAK & VYS & JMK & OLK & ZLK & MSK \\
\hline 1999 & 1,93 & 1,00 & 1,24 & 1,06 & 1,90 & 0,82 & 0,59 & 1,15 & 0,38 & 0,88 & 0,71 & 0,24 & 0,59 \\
\hline 2000 & 1,89 & 1,00 & 1,17 & 0,65 & 1,70 & 0,75 & 0,61 & 0,93 & 0,60 & 0,91 & 0,63 & 0,71 & 0,67 \\
\hline 2001 & 1,72 & 0,98 & 1,19 & 0,60 & 1,64 & 0,72 & 0,61 & 0,98 & 0,86 & 0,91 & 0,73 & 0,80 & 0,61 \\
\hline 2002 & 1,65 & 0,98 & 1,37 & 0,74 & 1,62 & 0,82 & 0,64 & 0,86 & 0,60 & 0,85 & 0,71 & 0,86 & 0,71 \\
\hline 2003 & 1,75 & 0,73 & 1,22 & 0,60 & 1,28 & 0,94 & 0,60 & 1,11 & 0,94 & 0,87 & 0,72 & 0,68 & 0,89 \\
\hline 2004 & 1,49 & 0,84 & 1,03 & 0,63 & 1,30 & 1,28 & 0,62 & 0,88 & 0,87 & 1,04 & 0,75 & 0,64 & 0,95 \\
\hline 2005 & 1,87 & 1,15 & 1,03 & 0,63 & 1,06 & 1,36 & 0,56 & 0,90 & 0,93 & 0,66 & 0,60 & 0,67 & 1,00 \\
\hline 2006 & 1,85 & 1,08 & 1,01 & 0,58 & 0,92 & 1,25 & 0,44 & 0,85 & 1,18 & 0,69 & 0,49 & 0,59 & 1,23 \\
\hline 2007 & 1,80 & 1,00 & 0,91 & 0,53 & 1,30 & 1,13 & 0,49 & 0,71 & 1,15 & 0,65 & 0,40 & 0,57 & 1,31 \\
\hline 2008 & 1,75 & 1,08 & 0,89 & 0,56 & 1,19 & 1,29 & 0,51 & 0,81 & 0,96 & 0,73 & 0,48 & 0,58 & 1,24 \\
\hline 2009 & 1,83 & 1,03 & 0,95 & 0,57 & 1,10 & 1,12 & 0,53 & 0,63 & 0,95 & 0,90 & 0,44 & 0,55 & 1,19 \\
\hline 2010 & 1,62 & 1,01 & 0,96 & 0,53 & 1,05 & 1,15 & 0,70 & 0,86 & 0,85 & 1,01 & 0,40 & 0,67 & 1,13 \\
\hline 2011 & 1,67 & 1,07 & 0,97 & 0,50 & 0,89 & 1,09 & 0,68 & 0,81 & 0,80 & 1,04 & 0,41 & 0,68 & 1,18 \\
\hline 2012 & 1,86 & 1,01 & 0,89 & 0,39 & 0,84 & 1,11 & 0,74 & 0,72 & 0,77 & 1,02 & 0,40 & 0,64 & 1,19 \\
\hline 2013 & 1,95 & 1,02 & 0,82 & 0,49 & 0,87 & 1,13 & 0,71 & 0,49 & 0,74 & 1,07 & 0,43 & 0,63 & 1,12 \\
\hline 2014 & 1,99 & 1,01 & 1,11 & 0,54 & 0,78 & 1,01 & 0,73 & 0,54 & 0,74 & 0,91 & 0,47 & 0,68 & 1,17 \\
\hline 2015 & 1,88 & 1,05 & 1,22 & 0,54 & 0,73 & 0,88 & 0,79 & 0,52 & 0,83 & 0,76 & 0,53 & 0,74 & 1,30 \\
\hline 2016 & 1,69 & 1,09 & 1,17 & 0,64 & 0,77 & 0,96 & 0,76 & 0,59 & 0,83 & 0,87 & 0,54 & 0,79 & 1,25 \\
\hline
\end{tabular}

Zdroj: Vlastní propočet dle dat ČNB (2019) a ČSÚ (2019); Vysvětlivky: viz tab. 1

V navazující analýze byl index lokalizace FDI porovnán s indexem lokalizace HDP (sledované období 1999 až 2016 na úrovni krajů). Výrazně nadproporcionální hodnoty vykazuje opět Středočeský kraj. Naopak nejnižší hodnoty vykazuje Karlovarský kraj. Klesající hodnotu 
indexu lokalizace HDP vykazují Jihočeský, Ústecký a Karlovarský kraj. Pozitivní trend vykazuje Plzeňský, Královéhradecký, Jihomoravský a Zlínský kraj (více viz Tab. 4).

Tab. 4. Vývoj indexu lokalizace HDP dle krajů ČR, 1999 až 2016 dle stavu investic $k 31.12$. a počtu zaměstnanců

\begin{tabular}{|l|r|r|r|r|r|r|r|r|r|r|r|r|r|}
\hline & STČ & JHČ & PLK & KVK & ÚSK & LBK & KHK & PAK & VYS & JMK & OLK & ZLK & MSK \\
\hline 1999 & 1,18 & 1,03 & 0,98 & 0,87 & 1,06 & 0,99 & 0,98 & 0,95 & 0,99 & 0,98 & 0,91 & 0,93 & 0,97 \\
\hline 2000 & 1,17 & 1,02 & 0,98 & 0,87 & 1,03 & 1,00 & 0,99 & 0,97 & 0,95 & 0,99 & 0,97 & 0,92 & 0,96 \\
\hline 2001 & 1,15 & 1,02 & 0,99 & 0,85 & 0,99 & 0,99 & 0,99 & 0,96 & 0,98 & 1,02 & 0,95 & 0,94 & 0,97 \\
\hline 2002 & 1,13 & 1,03 & 0,99 & 0,90 & 1,00 & 0,98 & 0,96 & 0,97 & 1,00 & 1,03 & 0,93 & 0,95 & 0,96 \\
\hline 2003 & 1,14 & 1,01 & 1,02 & 0,87 & 1,04 & 0,91 & 0,96 & 0,97 & 1,02 & 1,03 & 0,93 & 0,93 & 0,97 \\
\hline 2004 & 1,11 & 1,00 & 1,03 & 0,86 & 1,01 & 0,88 & 1,01 & 0,94 & 0,96 & 1,02 & 0,97 & 0,91 & 1,03 \\
\hline 2005 & 1,11 & 1,02 & 0,98 & 0,82 & 1,03 & 0,94 & 0,97 & 0,93 & 0,99 & 1,01 & 0,92 & 0,96 & 1,05 \\
\hline 2006 & 1,12 & 1,01 & 1,02 & 0,81 & 1,03 & 0,94 & 0,95 & 0,96 & 0,98 & 1,02 & 0,88 & 0,97 & 1,04 \\
\hline 2007 & 1,11 & 0,97 & 1,01 & 0,84 & 1,04 & 0,92 & 0,98 & 0,96 & 0,98 & 1,03 & 0,89 & 0,94 & 1,04 \\
\hline 2008 & 1,13 & 0,94 & 0,95 & 0,80 & 1,00 & 0,93 & 1,00 & 0,96 & 0,96 & 1,04 & 0,92 & 0,98 & 1,05 \\
\hline 2009 & 1,08 & 0,97 & 0,99 & 0,84 & 1,04 & 0,91 & 1,01 & 0,95 & 0,98 & 1,04 & 0,91 & 1,00 & 1,01 \\
\hline 2010 & 1,08 & 0,95 & 1,00 & 0,82 & 0,99 & 0,92 & 1,03 & 0,96 & 0,98 & 1,04 & 0,96 & 1,00 & 1,03 \\
\hline 2011 & 1,09 & 0,93 & 1,00 & 0,81 & 0,97 & 0,91 & 1,00 & 0,96 & 0,99 & 1,04 & 0,96 & 0,99 & 1,05 \\
\hline 2012 & 1,09 & 0,95 & 0,97 & 0,81 & 1,00 & 0,95 & 1,00 & 0,91 & 1,01 & 1,05 & 0,94 & 0,99 & 1,04 \\
\hline 2013 & 1,09 & 0,97 & 1,00 & 0,83 & 0,97 & 0,95 & 1,01 & 0,91 & 0,99 & 1,07 & 0,96 & 0,96 & 1,00 \\
\hline 2014 & 1,15 & 0,94 & 1,05 & 0,80 & 0,93 & 0,92 & 1,04 & 0,89 & 0,96 & 1,06 & 0,92 & 1,02 & 1,00 \\
\hline 2015 & 1,13 & 0,93 & 1,04 & 0,78 & 0,98 & 0,93 & 1,03 & 0,90 & 0,98 & 1,06 & 0,92 & 0,98 & 1,01 \\
\hline 2016 & 1,17 & 0,93 & 1,06 & 0,78 & 0,92 & 0,94 & 1,05 & 0,93 & 0,96 & 1,05 & 0,91 & 0,98 & 0,99 \\
\hline
\end{tabular}

Zdroj: Vlastní propočet dle dat ČSÚ (2019); Vysvětlivky: viz tab. 1

Jak již bylo zmíněno výše, př́imé zahraniční investice zvyšují ekonomický potenciál regionálních ekonomik. Jejich realizace tak představuje př́ležitost pro ekonomický rozvoj a růst regionálních ekonomik. Provázanost přímých zahraničních investic a hrubého domácího produktu lze doložit na základě korelace mezi indexy lokalizace těchto ukazatelů. Hodnota korelačního koeficientu osciluje v letech 1999 až 2016 mezi hodnotami 0,51 a 0,80 (viz Obr. 2).

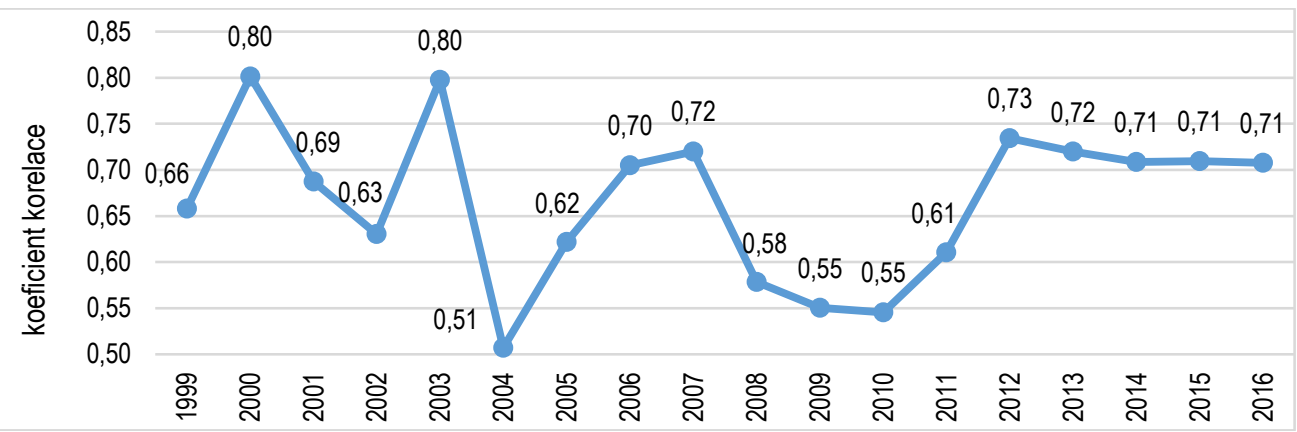

Obr. 2. Vývoj koeficientu korelace indexu lokalizace HDP a indexu lokalizace FDI, krajská úroven̆, 1999 až 2016; Zdroj: Vlastní zpracování a propočty dle dat ČNB (2019) a ČSÚ (2019)

Rozložení hodnot dokládá Obr. 3. Ačkoliv nelze relevantně zhodnotit kauzalitu mezi HDP a FDI (a není to ani cílem tohoto článku), je zřejmé, že přímé zahraniční investice směřuji do krajů ČR $\mathrm{s}$ vyšším hrubým domácím produktem a tím přispívají ke zvyšování rozdílů $\mathrm{v}$ ekonomické úrovni krajů České republiky. Je to zřejmé zvláště v letech 2000, 2003 a období 2012 až 2016, kdy koeficient korelace dosáhl hodnoty nad 0,7. 


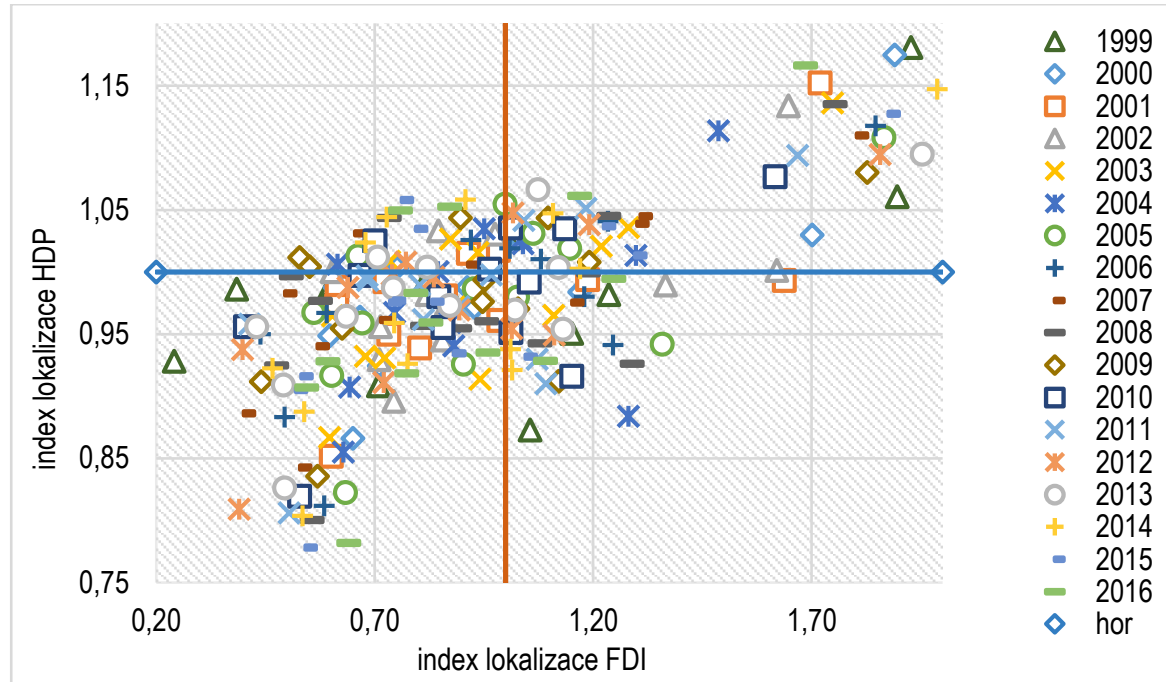

Obr. 3. Rozložení hodnot indexů lokalizace FDI a HDP, krajská úroveň, 1999 až 2016; Zdroj: Vlastni zpracování a propočty dle dat ČNB (2019) a ČSÚ (2019)

Z hlediska regionálních disparit je klíčové rozložení dle jednotlivých částí grafů. Ke snižování regionálních rozdílů přispívají regiony, kde je nadproporcionální zastoupení FDI a podproporcionální zastoupení HDP (kvadrant D) nebo podproporcionální zastoupení HDP a nadproporcionální zastoupení FDI (kvadrant B). Naopak, regiony nacházející se v kvadrantech A a C, tj. nadproporcionální zastoupení FDI i HDP nebo naopak jejich podproporcionální zastoupení, zvyšují regionální disparity. To ukazuje navazující Obr. 4. Počet regionů v kvadrantech B a D výrazně převyšuje regiony v kvadrantech A a C.

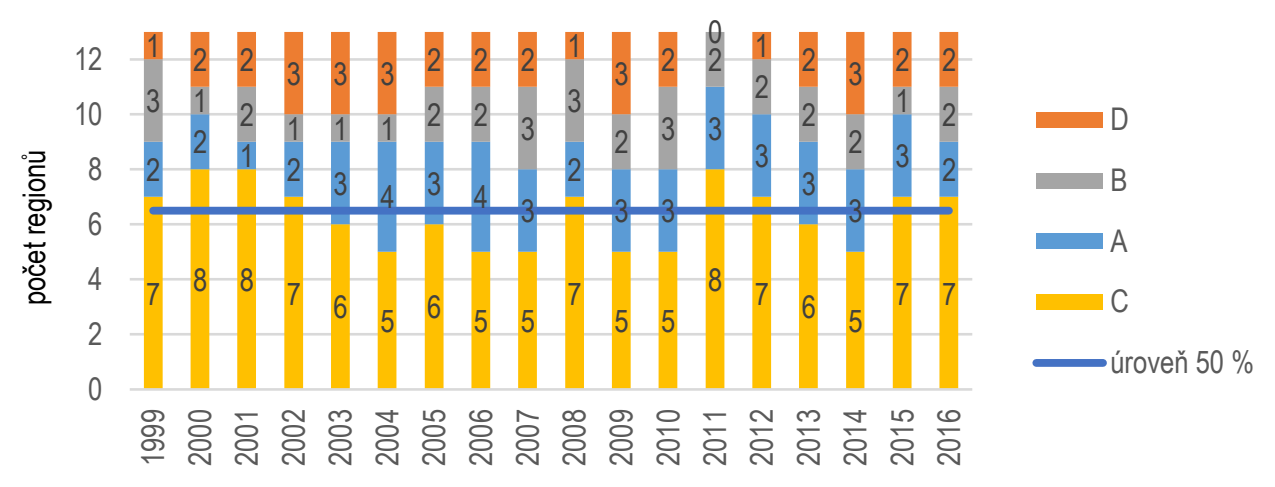

Obr. 4. Zastoupení regionů v jednotlivých kvadrantech dle indexů lokalizace FDI a HDP, kraje $\check{C} R, 1999$ - 2016 - stav investic k 31. 12. Zdroj: Vlastni propočet dat ČNB (2019) a ČSÚ (2019)

Podobné rozložení lokalizačního indexu jako HDP vykazuje také hrubá přidaná hodnota (HPH). Výrazně nadproporcionální hodnoty vykazuje opět Středočeský kraj. Naopak nejnižší hodnoty vykazuje Karlovarský kraj. Klesající hodnotu indexu lokalizace HDP vykazuje Jihočeský, Ústecký a Karlovarský kraj. Pozitivní trend vykazuje Plzeňský, Královéhradecký a Jihomoravský kraj (viz Tab. 5). 
Tab. 5. Vývoj indexu lokalizace HPH dle krajů ČR, 1999 až 2016 dle stavu investic k 31. 12. a počtu zaměstnanců

\begin{tabular}{|l|r|r|r|r|r|r|r|r|r|r|r|r|r|}
\hline & STČ & JHČ & PLK & KVK & ÚSK & LBK & KHK & PAK & VYS & JMK & OLK & ZLK & MSK \\
\hline 1999 & 1,18 & 1,03 & 0,98 & 0,87 & 1,06 & 0,99 & 0,98 & 0,95 & 0,99 & 0,98 & 0,91 & 0,93 & 0,97 \\
\hline 2000 & 1,17 & 1,02 & 0,98 & 0,87 & 1,03 & 1,00 & 0,99 & 0,97 & 0,95 & 0,99 & 0,97 & 0,92 & 0,96 \\
\hline 2001 & 1,15 & 1,02 & 0,99 & 0,85 & 0,99 & 0,99 & 0,99 & 0,96 & 0,98 & 1,02 & 0,95 & 0,94 & 0,97 \\
\hline 2002 & 1,13 & 1,03 & 0,99 & 0,90 & 1,00 & 0,98 & 0,96 & 0,97 & 1,00 & 1,03 & 0,93 & 0,95 & 0,96 \\
\hline 2003 & 1,14 & 1,01 & 1,02 & 0,87 & 1,04 & 0,91 & 0,96 & 0,97 & 1,02 & 1,03 & 0,93 & 0,93 & 0,97 \\
\hline 2004 & 1,11 & 1,00 & 1,03 & 0,86 & 1,01 & 0,88 & 1,01 & 0,94 & 0,96 & 1,02 & 0,97 & 0,91 & 1,03 \\
\hline 2005 & 1,11 & 1,02 & 0,98 & 0,82 & 1,03 & 0,94 & 0,97 & 0,93 & 0,99 & 1,01 & 0,92 & 0,96 & 1,05 \\
\hline 2006 & 1,12 & 1,01 & 1,02 & 0,81 & 1,03 & 0,94 & 0,95 & 0,96 & 0,98 & 1,02 & 0,88 & 0,97 & 1,04 \\
\hline 2007 & 1,11 & 0,97 & 1,01 & 0,84 & 1,04 & 0,92 & 0,98 & 0,96 & 0,98 & 1,03 & 0,89 & 0,94 & 1,04 \\
\hline 2008 & 1,13 & 0,94 & 0,95 & 0,80 & 1,00 & 0,93 & 1,00 & 0,96 & 0,96 & 1,04 & 0,92 & 0,98 & 1,05 \\
\hline 2009 & 1,08 & 0,97 & 0,99 & 0,84 & 1,04 & 0,91 & 1,01 & 0,95 & 0,98 & 1,04 & 0,91 & 1,00 & 1,01 \\
\hline 2010 & 1,08 & 0,95 & 1,00 & 0,82 & 0,99 & 0,92 & 1,03 & 0,96 & 0,98 & 1,04 & 0,96 & 1,00 & 1,03 \\
\hline 2011 & 1,09 & 0,93 & 1,00 & 0,81 & 0,97 & 0,91 & 1,00 & 0,96 & 0,99 & 1,04 & 0,96 & 0,99 & 1,05 \\
\hline 2012 & 1,09 & 0,95 & 0,97 & 0,81 & 1,00 & 0,95 & 1,00 & 0,91 & 1,01 & 1,05 & 0,94 & 0,99 & 1,04 \\
\hline 2013 & 1,09 & 0,97 & 1,00 & 0,83 & 0,97 & 0,95 & 1,01 & 0,91 & 0,99 & 1,07 & 0,96 & 0,96 & 1,00 \\
\hline 2014 & 1,15 & 0,94 & 1,05 & 0,80 & 0,93 & 0,92 & 1,04 & 0,89 & 0,96 & 1,06 & 0,92 & 1,02 & 1,00 \\
\hline 2015 & 1,13 & 0,93 & 1,04 & 0,78 & 0,98 & 0,93 & 1,03 & 0,90 & 0,98 & 1,06 & 0,92 & 0,98 & 1,01 \\
\hline 2016 & 1,17 & 0,93 & 1,06 & 0,78 & 0,92 & 0,94 & 1,05 & 0,93 & 0,96 & 1,05 & 0,91 & 0,98 & 0,99 \\
\hline
\end{tabular}

Zdroj: Vlastni propočet dle dat ČSÚ (2019); Vysvětlivky: viz tab. 1

Korelační koeficienty indexů lokalizace HPH a FDI mají velmi podobný vývoj jako v př́padě HDP a FDI. V celém sledovaném období 1999 až 2016 je hodnota kladná a pohybuje se v intervalu 0,51 až 0,80 . I z tohoto hlediska se potvrzuje, že FDI směřují nadproporcionálně do ekonomicky silnejjších regionů (viz Obr. 5).

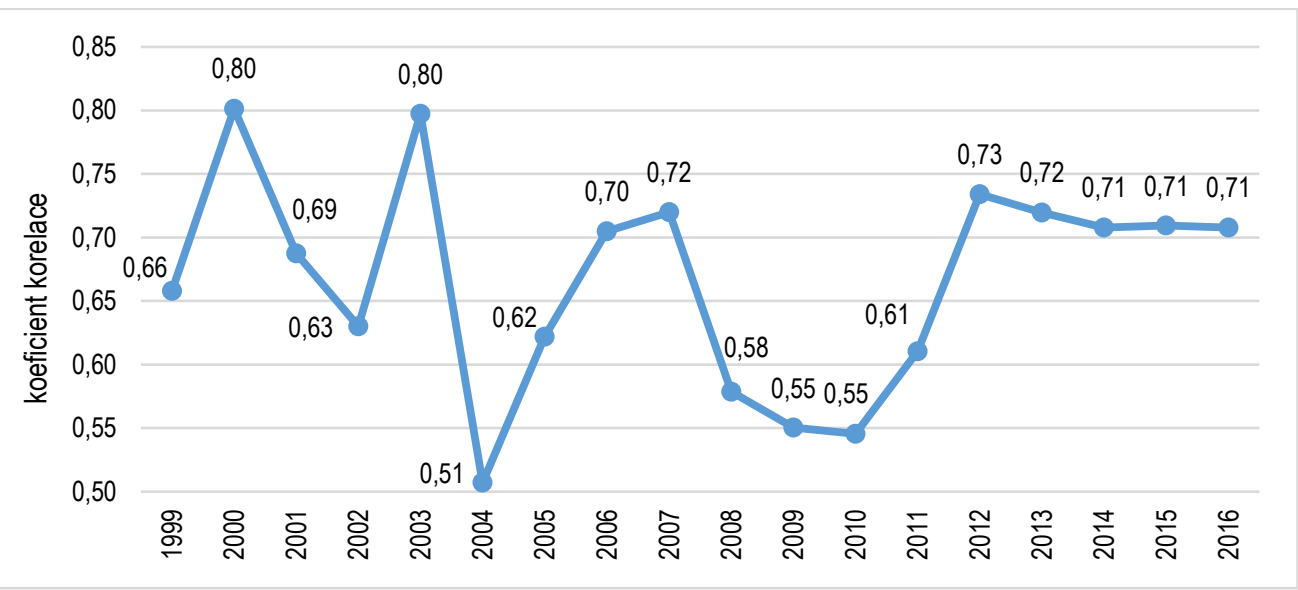

Obr. 5. Vývoj koeficientu korelace indexu lokalizace HPH a indexu lokalizace FDI, krajská úroveň, 1999 až 2016; Zdroj: Vlastní zpracováni a propočty dle dat ČNB (2019) a ČSÚ (2019)

Vzájemný vztah indexů lokalizace FDI a HPH dokládá Obr. 6. Obdobně jako u HDP a FDI platí, že ačkoliv nelze relevantně zhodnotit kauzalitu mezi HPH a FDI, je zřejmé, že prrímé zahraniční investice směřují do krajů ČR s vyšší přidanou hodnotou a tím přispívají ke zvyšování rozdílů v ekonomické úrovni krajů České republiky. 


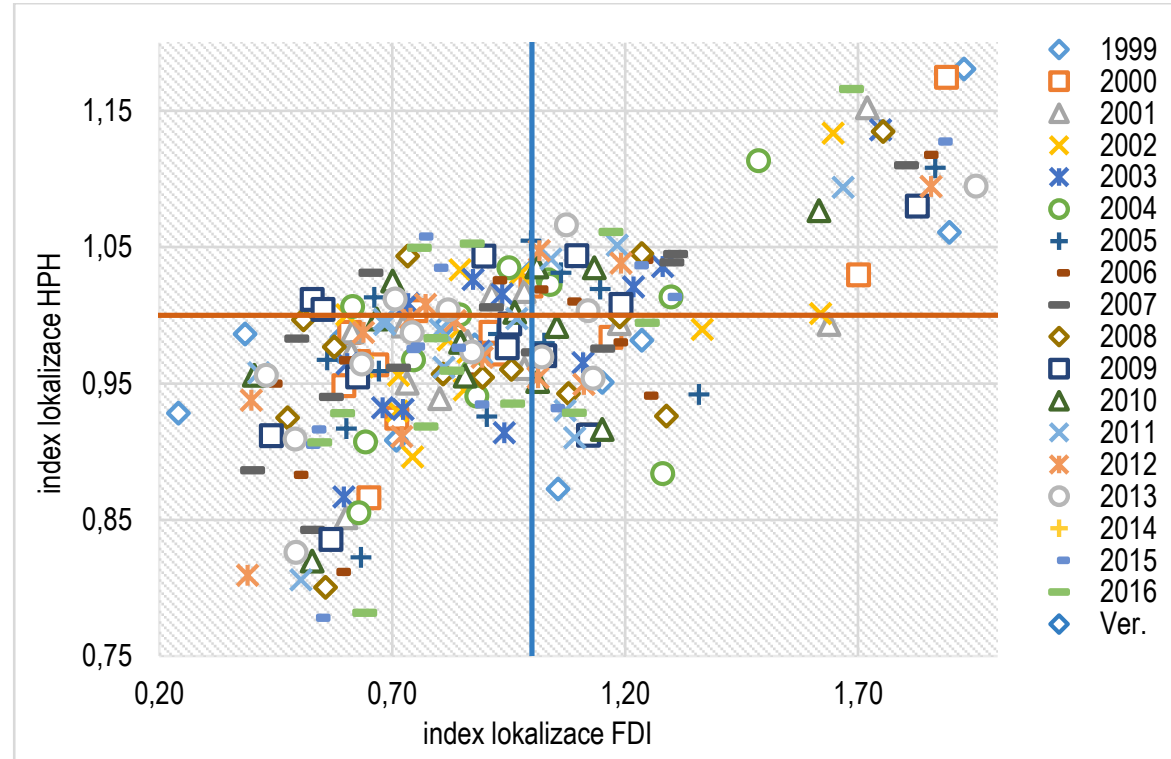

Obr. 6. Rozložení hodnot indexů lokalizace FDI a HPH, krajská úroveň, 1999 až 2016; Zdroj: Vlastní zpracování a propočty dle dat ČNB (2019) a ČSÚ (2019)

Z hlediska regionálních disparit je klíčové četnostní rozložení dle jednotlivých kvadrantů grafu. Ke snižování regionálních rozdílů přispívají regiony, kde je nadproporcionální zastoupení HPH a podproporcionální zastoupení FDI (kvadrant D) nebo podproporcionální zastoupení FDI a nadproporcionální zastoupení HPH (kvadrant B). Naopak, regiony nacházející se v kvadrantech A a C, tj. nadproporcionální zastoupení FDI i HDP nebo naopak jejich podproporcionální zastoupení, přispívají k růstu regionálních rozdílů. Počet regionů v kvadrantech $\mathrm{A}$ a $\mathrm{C}$ výrazně převyšuje regiony v kvadrantech $\mathrm{B}$ a $\mathrm{D}$ (rozložení viz Obr. 7).

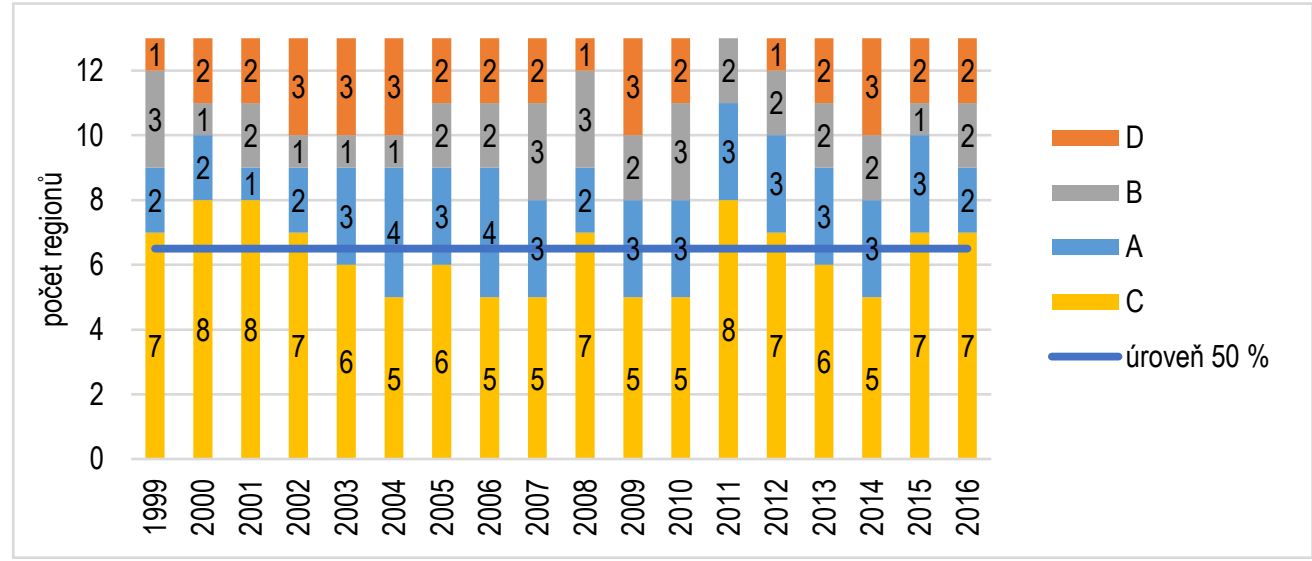

Obr. 7. Rozložení hodnot indexů lokalizace FDI a HPH, krajská úroveň, 1999 až 2016; Zdroj: Vlastní zpracování a propočty dle dat ČNB (2019) a ČSÚ (2019)

Nezaměstnanost je tradičním problémem Ústeckého a Moravskoslezského kraje. Nadprůměrné hodnoty vykazují také Karlovarský a Olomoucký kraj. Karlovarský kraj se od počátku 90. let potýká se strukturálními problémy v ekonomice. Nezaměstnanost Olomouckého kraje se koncentruje do periferních částí (tj. Šumpersko a Jesenicko) a Přerovska. Naopak nejpříznivější hodnoty vykazují Plzeňský, Královéhradecký a Pardubický kraj. Pohled na 
problematiku nezaměstnanosti poskytuje Tab. 6 , která poskytuje data o koncentraci nezaměstnaných vůči počtu zaměstnanců (index koncentrace nezaměstnaných - UN - ekvivalentní vůči výše zmíněným indexům).

Koncentrace nezaměstnaných a FDI (dle indexů lokalizace) je dle korelačního koeficientu fakticky nezávislá. Hodnoty oscilují mezi statisticky nevýznamnými hodnotami 0,17 a -0,26. Korelace nepotvrdila směřování FDI do regionů s nadproporcionálním nebo podproporcionálním zastoupením nezaměstnaných (viz Obr. 8).

Z hlediska regionálních disparit je klíčové četnostní rozložení dle jednotlivých kvadrantů grafu. Ke zvyšování regionálních rozdílů přispívají regiony, kde je nadproporcionální (nebo podproporcionální) zastoupení obou sledovaných hodnot (kvadranty A a C). Naopak, kvadranty, kde je jedna hodnota podproporcionální a druhá nadproporcionální (kvadranty B a D) vedou ke snižování rozdílů (rozložení viz Obr. 9).

Tab. 6. Vývoj indexu nezaměstnaných dle krajů ČR, 1999 až 2016 dle počtu nezaměstnaných $k$ 31. 12. a počtu zaměstnanců

\begin{tabular}{|l|r|r|r|r|r|r|r|r|r|r|r|r|r|}
\hline & STČ & JHČ & PLK & KVK & ÚSK & LBK & KHK & PAK & VYS & JMK & OLK & ZLK & MSK \\
\hline 2000 & 0,73 & 0,59 & 0,64 & 0,80 & 1,83 & 0,66 & 0,58 & 0,81 & 0,79 & 0,94 & 1,32 & 0,82 & 1,69 \\
\hline 2001 & 0,70 & 0,61 & 0,64 & 0,86 & 1,81 & 0,74 & 0,61 & 0,80 & 0,73 & 0,97 & 1,27 & 0,85 & 1,67 \\
\hline 2002 & 0,67 & 0,60 & 0,62 & 0,91 & 1,77 & 0,80 & 0,64 & 0,79 & 0,79 & 1,03 & 1,18 & 0,93 & 1,59 \\
\hline 2003 & 0,69 & 0,60 & 0,64 & 0,91 & 1,74 & 0,83 & 0,67 & 0,82 & 0,85 & 0,98 & 1,15 & 0,92 & 1,61 \\
\hline 2004 & 0,67 & 0,62 & 0,61 & 1,01 & 1,67 & 0,79 & 0,71 & 0,82 & 0,85 & 1,00 & 1,16 & 0,93 & 1,62 \\
\hline 2005 & 0,68 & 0,68 & 0,62 & 1,01 & 1,72 & 0,79 & 0,71 & 0,81 & 0,85 & 1,02 & 1,10 & 0,95 & 1,54 \\
\hline 2006 & 0,65 & 0,67 & 0,62 & 1,06 & 1,77 & 0,83 & 0,72 & 0,79 & 0,85 & 1,00 & 1,06 & 0,93 & 1,57 \\
\hline 2007 & 0,66 & 0,68 & 0,65 & 1,11 & 1,80 & 0,91 & 0,70 & 0,79 & 0,85 & 1,01 & 1,01 & 0,91 & 1,53 \\
\hline 2008 & 0,72 & 0,72 & 0,76 & 1,14 & 1,59 & 1,08 & 0,73 & 0,90 & 0,98 & 0,97 & 1,06 & 0,91 & 1,33 \\
\hline 2009 & 0,73 & 0,75 & 0,79 & 1,10 & 1,40 & 1,12 & 0,76 & 0,94 & 1,03 & 0,98 & 1,20 & 1,04 & 1,23 \\
\hline 2010 & 0,78 & 0,77 & 0,77 & 1,10 & 1,37 & 1,04 & 0,78 & 0,91 & 1,04 & 0,98 & 1,22 & 1,00 & 1,23 \\
\hline 2011 & 0,80 & 0,77 & 0,73 & 1,08 & 1,44 & 1,05 & 0,77 & 0,87 & 1,00 & 0,99 & 1,23 & 0,97 & 1,24 \\
\hline 2012 & 0,80 & 0,79 & 0,70 & 1,09 & 1,47 & 1,05 & 0,82 & 0,87 & 0,99 & 0,96 & 1,18 & 1,00 & 1,24 \\
\hline 2013 & 0,83 & 0,81 & 0,69 & 1,10 & 1,43 & 1,04 & 0,85 & 0,83 & 0,93 & 0,95 & 1,21 & 0,94 & 1,27 \\
\hline 2014 & 0,86 & 0,78 & 0,70 & 1,08 & 1,45 & 1,02 & 0,83 & 0,74 & 0,92 & 0,97 & 1,16 & 0,92 & 1,31 \\
\hline 2015 & 0,86 & 0,76 & 0,68 & 1,10 & 1,49 & 1,02 & 0,76 & 0,74 & 0,95 & 0,98 & 1,11 & 0,88 & 1,38 \\
\hline 2016 & 0,83 & 0,77 & 0,65 & 1,06 & 1,53 & 1,00 & 0,69 & 0,72 & 0,91 & 1,02 & 1,10 & 0,87 & 1,43 \\
\hline
\end{tabular}

Zdroj: Vlastni propočet dle dat ČSÚ (2019); Vysvětlivky: viz tab. 1

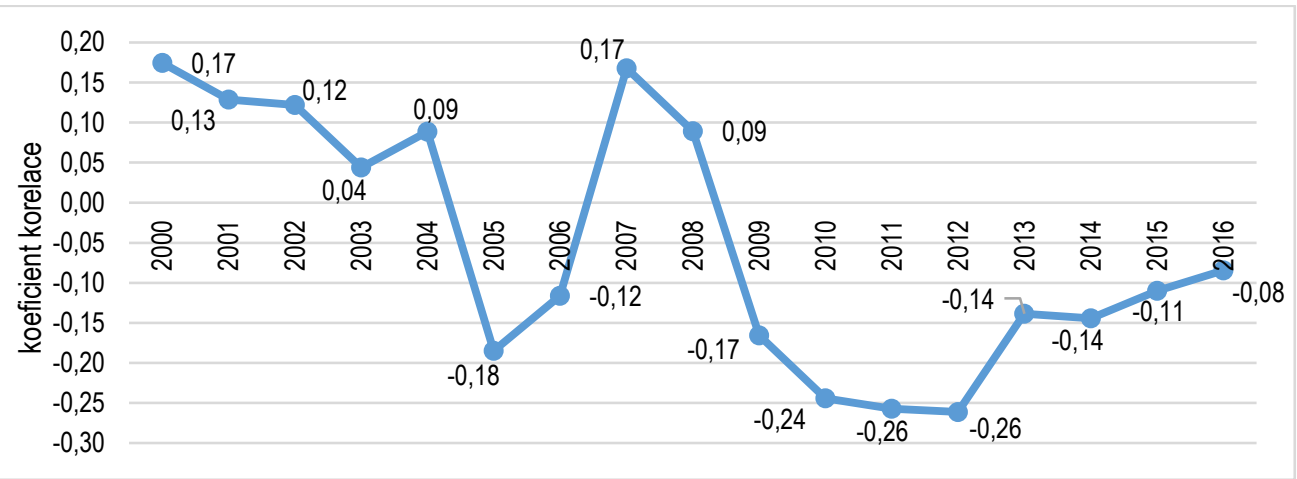

Obr. 8. Vývoj koeficientu korelace indexu lokalizace UN a indexu lokalizace FDI, krajská úroven̆, 1999 až 2016; Zdroj: Vlastní zpracováni a propočty dle dat ČNB (2019) a ČSÚ (2019) 


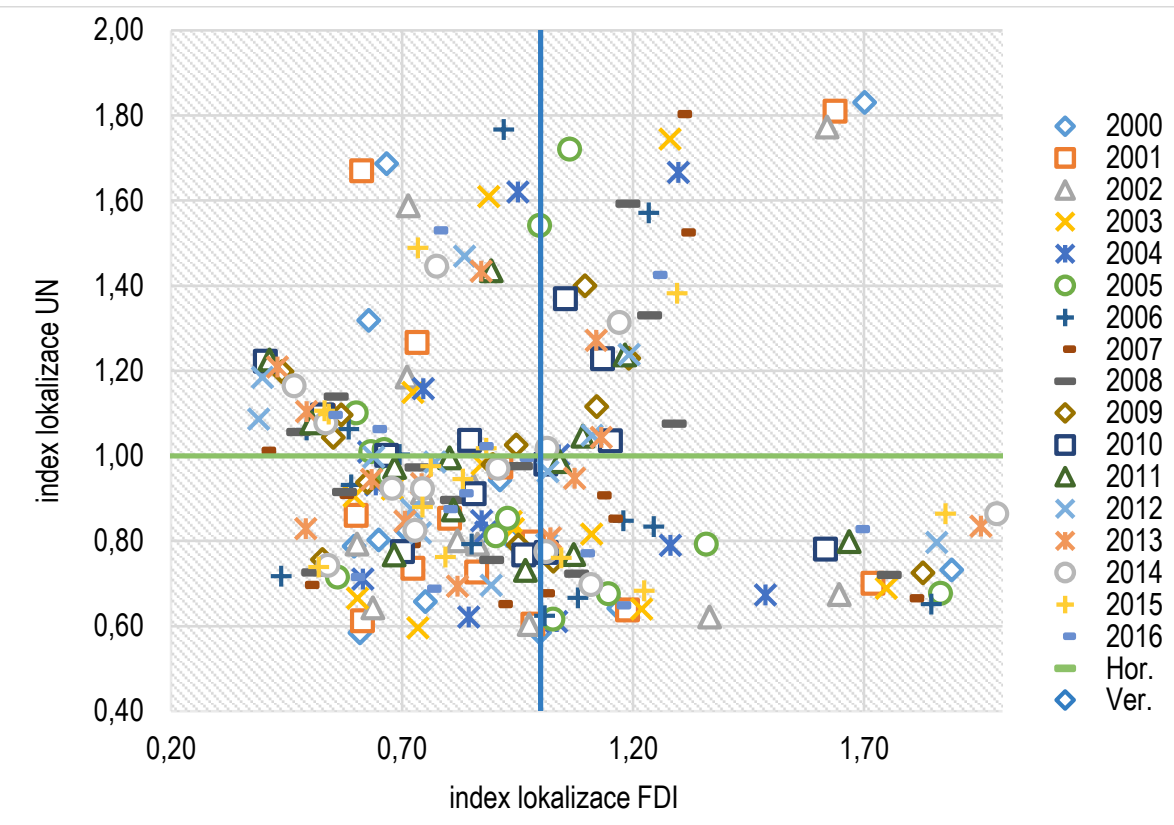

Obr. 9. Rozložení hodnot indexů lokalizace FDI a UN, krajská úroveň, 1999 až 2016; Zdroj: Vlastní zpracováni a propočty dle dat ČNB (2019) a ČSÚ (2019)

$\mathrm{Z}$ poměru počtu regionů zařazených do kvadrantů $\mathrm{A}$ a $\mathrm{C}$ a kvadrantů $\mathrm{B}$ a $\mathrm{D}$, mírně převládají regiony zařazené do kvadrantu A a C. Neplatí to však ve všech letech. V letech 2005 , 2006, 2007, 2010, 2015 a 2016 mírně převládají regiony v kvadrantech B a C. Rozdíly však nejsou př́lišs výrazné a nelze určit jednoznačný závěr o směřování investic k regionálnímu rozložení nezaměstnaných (viz obr. 10).

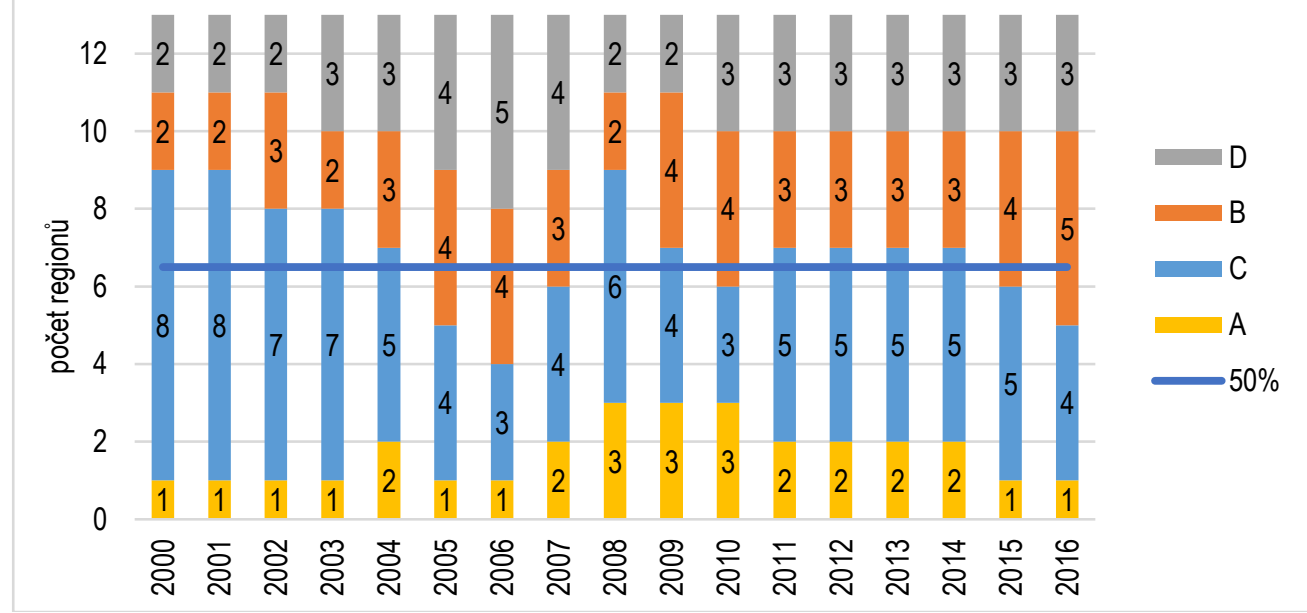

Obr. 10. Rozložení hodnot indexů lokalizace FDI a UN v jednotlivých kvadrantech, krajská úroveň, 1999 až 2016; Zdroj: Vlastní zpracování a propočty dle dat ČNB (2019) a ČSÚ (2019) 


\section{Diskuse}

Provedená analýza potvrdila, že FDI mají koncentrační charakter, což potvrzuje koncentrační tendence v regionálních ekonomikách, např. Rychen, Zimmermann 2008, Phelps 2008, Grote, Taeube 2006, Baldwin et al. 2008. Naopak dekoncentrační faktory (např. Fujita 1999 nebo Pelegrin, Bolancé 2008, Vernon 1966, Markusen 1985) lze označit za relativně slabší. Ani regionalizace investičních pobídek tento trend nedokáže změnit.

Provedená analýza potvrdila a rozšíriila některé již publikované poznatky. Pavlínek (2009) uvádí, že v kontextu střední Evropy jsou FDI typické koncentrací v prostoru a nerovnoměrným rozložením na všech úrovních - od globální, přes mezinárodní, národní až po regionální. Dále Pavlínek (2009) uvádí, že historicky jde nejvíce investic do hlavních měst, které jsou obvykle také městy největšími, a do dalších velkých městských oblastí. Analýza potvrdila, že rozdíly ve směřování investic neurčuje jen prítomnost velkého města, ale obecně se dá identifikovat vztah mezi vyšši ekonomickou úrovní regionu (typická právě pro velká města) a úrovní př́livu prímých zahraničních investic. To je dáno tím, že FDI jsou nejen přitahovány do ekonomických klastrů, kde mohou být získány externí úspory, ale FDI tyto klastry přímo vytvárí. Proto také platí poznatek Pavlínka (2009), že vyspělé a více industrializované regiony přitahují větší objem investic než regiony méně rozvinuté a méně industrializované (od roku 1990). Tento trend ještě prohlubuje rostoucí podíl reinvestovaného zisku, který přirozeně vede k další koncentraci FDI. Potvrzuje se také poznatek Viturky (2014), že FDI na jedné straně reagují na rozvojový potenciál regionu, ale zároveň jej také tvoří. K podobnému poznatku dospěl také Sucháček (2013), který dále navazuje konstatováním, že toto je důvodem proč dochází k určité soutěži v lokalizaci investic mezi regiony.

Provedená analýza prezentovaná v tomto článku poukazuje, že přechod České republiky od transitivní do post-transitivní ekonomiky identifikované trendy nijak nezměnil.

\section{Závěr}

Cílem článku je zhodnotit roli př́mých zahraničních investic (FDI) ve snižování nebo zvyšování meziregionálních rozdílů v ekonomické úrovni. Tento cíl byl konkretizován do podoby hypotézy: „Př́ímé zahraniční investice směřují nadproporcionálně do regionů s vyšší ekonomickou úrovní a tím prohlubují rozdíly v ekonomické úrovni jednotlivých regionů České republiky“.

V teoretické části jsou zhodnoceny dopady př́mých zahraničních investic na ekonomiky v obecné rovině. Pozornost je věnována jejich vlivu na trhu práce, transferu technologií, vlivu na domácí firmy, exportnímu potenciálu a dalším. Tato témata byla zvolena s ohledem na př́mou vazbu mezi FDI a ekonomickým výkonem regionu. Ačkoliv je možno najít studie poukazující na negativní dopady FDI, z provedeného sekundárního výzkumu vyplývá, že pozitivní hodnocení FDI mezi ekonomy převládá. FDI jsou považovány za exogenní faktor růstu přispívající $\mathrm{k}$ rozvoji hostitelských regionálních ekonomik. Zejména těch, které zaostávají prostřednictvím poptávkové stimulace, růstu zaměstnanosti a mezd a růstu exportního potenciálu.

Primárním cílem provedené navazující koncentrační analýzy bylo ověřit výše stanovenou hypotézu o směřování FDI. Koncentrační analýza s využitím korelace prokázala, že přímé zahraniční investice nadproporcionálně směřují do regionů s vyšší ekonomickou úrovní a tím přispívají k prohloubení meziregionálních rozdílů v ekonomické úrovni krajů České republiky při měření ekonomického výkonu ukazateli (a) hrubý domácí produkt, (b) hrubá přidaná hodnota, (c) počet nezaměstnaných. Provedená analýza potvrdila zvýšený objem investic v regionech s vyšším hrubým domácím produktem i hrubou přidanou hodnotou v celém sledovaném období 1999 až 2016. Tento trend ještě prohlubuje rostoucí podíl reinvestovaného zisku, který přirozeně vede k další koncentraci FDI. Naopak v případě vazby koncentrace FDI a nezaměstnaných jsou výsledky nejednoznačné.

Mezi sledovanými regiony je investičně jednoznačně nejatraktivnějším Středočeský kraj, který získává jak ze své blízkosti hlavnímu městu, tak lokalizace významných průmyslových 
investic, zejména Škoda Auto nebo TPCA. Naopak mezi regiony nejméně rozvinuté lze zařadit kraje Karlovarský, Ústecký a také Moravskoslezský, ve kterém jsou makroekonomické ukazatele poměrně příznivé, nicméně v kraji nebyly plně vyřešeny strukturální problémy plynoucí z nastavení regionální ekonomiky před rokem 1990. V těchto regionech lze identifikovat velmi rozdílný trend. Zatímco oba kraje NUTS II Severozápad (Karlovarský i Ústecký kraj) vykazovaly v roce 1999 nadproporcionální hodnoty FDI, Moravskoslezský kraj byl výrazně podproporcionální. Zcela opačné vývojové trendy způsobily současné rozdílné postavení krajů. V př́padě Moravskoslezského kraje tento index vzrostl na dvojnásobek. Příčiny špatného vývoje a situace Karlovarského a Ústeckého kraje jsou zejména problémy ve vzdělanostní struktuře pracovní síly se zastoupením málo kvalifikované pracovní síly. Strukturální problémy regionu se zde projevují již od poloviny 90 . let, kdy došlo k útlumu v tradičních průmyslových odvětvích (zejména těžební a chemický) a navazujících odvětvích. Velkým problémem Karlovarského kraje je dopravní napojení a velmi omezené terciální vzdělávání.

Zjištěné skutečnosti lze označit za velmi významné z hlediska stanovených cílů regionální politiky, jak je definuje např́klad Strategie regionálního rozvoje ČR 2014 až 2020. V návaznosti na uvedené cíle je možno přehodnotit dosud užívané nástroje regionální politiky ve formě investičních pobídek. Náhled na př́mé zahraniční investice realizované v ČR jako na klíčový element regionálního rozvoje je v regionální politice spíše výjimečný a ve většině př́ípadů se omezuje na prosté obecné konstatování, že FDI hrají roli a úkolem samosprávy je zvyšovat investiční atraktivnost regionu. A nejen s ohledem na tuto skutečnost by si téma FDI zasloužilo další analýzu zaměřenou zejména na důležitost lokalizačních faktorů, které se v čase neustále proměňují, reálnou roli investičních pobídek v rozhodovacích procesech o umístění investice nebo zhodnocení rolí regionálních a místních samospráv ve vztahu k tvrdým i měkkým faktorům investiční atraktivnosti regionu.

\section{Literatura}

AITKEN, B. J., HARRISON, A. E. 1999: Do Domestic Firms Benefit from Direct Foreign Investment? Evidence from Venezuela. The American Economic Rexiew, 89(3), 605-618. DOI: https://doi.org/10.1257/aer.89.3.605.

BALDWIN, J. R., BECKSTEAD, D., BROWN, W. M., RIGBY, D. L. 2008: Agglomeration and the Geography of Localization Economies in Canada. Regional Studies, 42(2), 117132. DOI: https://doi.org/10.1080/00343400701543199.

BENÁČEK, V. 1999: Foreign Direct Investment in an Economy of Transition - The Case of the Czech Republic: Evalution, Problems and Policy Issues. Brusel (Science Report).

BERLE, A., MEANS, C. G. 1932: The Modern Corporation and Private Property. London (Transaction Publishers).

BORENSZTEIN, E., DE GREGORIO, J., LEE, J. W. 1998: How does foreign direct investment affect economic growth? Journal of Internation Economics, 45(1), 115-135. DOI: https://doi.org/10.3386/w5057.

CAPELLO, R. et. al. 2007: Regional economics. London (Routledge).

ČNB 2019: Př́́mé zahraniční investice, Dostupné na: https://www.cnb.cz/cs/statistika/ platebni_bilance_stat/publikace_pb/pzi/

ČSÚ 2019: Databáze regionálních účtu, Dostupné na: http://apl.czso.cz/pll/rocenka/ rocenka.indexnu_reg

DAMBORSKÝ, M., ŘÍHOVÁ, G. 2008: Přímé zahraniční investice v ČR. Regionální studia, 2(2), 22-28.

EDFELT, R. B. 1975: Direct Investment in a Developing Economy: Towards Evaluating the Human Resources Development Impact in Brazil - Ph.D. dissertation. Los Angeles (Univesity of California). 
FALLON, G., COOK, M. 2010: Exploring the Regional Distribution of Inbound Foreign Direct Investment in the UK in Theory and Practice: Evidence form a Five-Region Study. Regional Studies, 44(3), 337-353. DOI: https://doi.org/10.1080/00343400802378735.

FIFEKOVÁ, E., NEMCOVÁ, E. 2015: Impact of FDI on Economic Growth: Evidence from V4 Countries. Periodica Polytechnica Social and Management Sciences, 23(1), 7-14. DOI: https://doi.org/10.3311/PPso.7993.

FUJITA, M., KRUGMAN, P., VENABLES, A., 1999: The Spatial Economy: Cities, Regions and International Trade. Cambridge: MIT Press.

GALBRAITH, J. K. 1985: New Industrial State. Boston (Houghton Miffin Company).

GONCALVES, R. 1986: Technologicla Spillovers and Manpower Training: A Comparative Analisis of Multinational and National Enterprises in Brazlian Manufacturing. Journal of Development Economics, 11(1), 119-132.

GÖRG, H., GREENAWAY, D. 2004: Much Ado about Nothing? Do Domestic Firms Really Benefit form Foreign Direct Investment? The World Bank Research Observer, 19(2), 171197. DOI: https://www.doi.org/10.1093/wbro/lkh019.

GRAHAM, E. M., P. KRUGMAN 1995: Foreign Direct Investment in the United States (3 ${ }^{\text {rd }}$ edition). Washington (Institute for International Economics).

GROTE, M. H., TAEUBE, A. F. 2006: Offshoring the financial services industry: implications fo the evolution of Indian IT clusters. Environment and Planning, 38, 1287-1305. DOI: https://doi.org/10.1068/a37256.

HLAVÁČEK, P., BEATA, B. D. 2016: Impact of Foreign Direct Investment on Economic Growth in Central European Countries. Engineering Economics, 27(3), 294-303. DOI: https://doi.org/10.5755/j01.ee.27.3.3914.

CHOBOTOVÁ, M. 2014: Hodnocení vlivu př́mých zahraničních investic na rozvoj vybraných regionů. In Klímová, V., Žítek, V. eds. XVII. mezinárodní kolokvium o regionálních vědách. Sborník př́spěvků. Brno (Masarykova univerzita), pp. 150-156.

CHRISTALLER, W. 1966: Central Places in Southern Germany. New Jersey (Prentice Hall).

JAROLÍM, M. 2000: Foreign Direct Investment and Productivity of Firms. Czech Journal of Economics and Finance, 50(9), 478-487. Dostupné na: http://journal.fsv.cuni.cz/mag/article/show/id/610.

KOKKO, A. 1992: Foreign Direct Investment, Host Country Charakteristics and Spillovers. Stockholm (School of Economics).

KONINGS, J. 2001: The Effects of Foreign Direct Investment on Domestic Firms: Evidence from Firm-Level Panel Data in Emerging Economies. Economics of Transition, 9(3), 619633. DOI: https://doi.org/10.1111/1468-0351.00091.

KRUGMAN, P., VENABLES, A. 1995: Globalization and the Inequality of Nations. The Quarterly Journal of Economics, 110(4), 857-880. DOI: https://doi.org/10.3386/w5098.

LÖSCH, A. 1954: The Economics of Location. New Haven (Yale University Press).

MAIER, G., TÖDTLING, F. 1997: Regionálna a urganistická ekonomika. Bratislava (ELITA).

MARKUSEN, A. 1985: Profit Cycles, Oligopoly and Regional Development. Cambridge (MIT Press).

PAVLÍNEK, P. 2009: Regional Development Effects of Foreign Direct Investment in Central and Eastern Europe. V: Regional Diversity and Local Development in the New Member States. London (Palgrave Macmillan).

PAVLÍNEK, P. 2018: Global production networks, foreign direct investment, and supplier linkages in the integrated peripheries of the automotive industry. Economic Geography, 94(2), 141-165. DOI: https://doi.org/10.1080/00130095.2017.1393313. 
PELEGRIN, A., BOLANCÉ, C. 2008: Regional Foreign Direct Investment in Manufacturing, Do Agglomeration Economies Matter? Regional Studies, 46(4), 505-522. DOI: https://doi.org/10.1080/00343400701543157.

PHELPS, N. A. 2008: Cluster of Capture? Manufacturing Foreign Direct Investment, External Economies and Agglomeration. Regional Studies, 42, 457-473. DOI: https://doi.org/ 10.1080/00343400701543256.

RYCHEN, F., ZIMMERMANN, J. 2008: Clusters in the Global Knowledge - base Economy: Knowledge Gatekeepers and Temporary Proximity. Regional Studies, 42(6), 767-776. DOI: https://doi.org/10.1080/00343400802088300.

SCHWARZ, J. a kol. 2007: Analýza investičnich pobidek v České republice. Praha (Národohospodářská fakulta, VŠE Praha).

SOLOW, R. 1956: A contribution to the theory of economic growth. Quarterly Journal of Economics, 70(1), 65-94. DOI: https://doi.org/10.2307/1884513.

SRHOLEC, M. 2004: Přmíné zahraniční investice v České republice. Praha (Linde).

SUCHÁČEK, J. 2013: Lokalizace investic z pohledu městských a regionálních aktivit v České republice. Ostrava (VŠB-Technical University of Ostrava).

TEECE, D. J. 1977: Technology Transfer by Multinational Firms: The Resource cost of Transferring Technological Know-how. Economic Journal, 87(346), 242-261. DOI: https://doi.org/10.2307/2232084.

VERNON, R. 1966: International investment and international trade in the product cycle. Quarterly Journal of Economics, 80, 190-207. DOI: https://doi.org/10.2307/1880689.

VITURKA, M. 2018: Integrative model for evaluation of development potentials of regions and its application on an example of the Czech Republic. $E$ and $M$ Ekonomie a management, 17(4), 4-19. DOI: https://doi.org/10.15240/tul/001/2014-4-001.

VON THÜNEN, J. H. 1826: Der Isolierte Staat in Beziehung auf Landwirtschaft und Nationalökonomie. Hamburg (Puthes).

WAGNER, J. 2014: Export, foreign direct investment and producitivity: are sevices firms dirrent? Service Industrie Journal, 34(1), 24-37. DOI: https://doi.org/10.1080/02642069. 2013.763344.

WEBER, A. 1969: Theory of the Location of Industries. Chicago (University of Chicago).

WOKOUN, R. a kol. 2010: Př́mé zahraniční investice a regionální rozvoj (1. vydání). Praha (Oeconomica).

ZAMRAZILOVÁ E. 2007: Př́mé zahraniční investice v české ekonomice: rizika duality a role trhu práce. Politická ekonomie, 65(5), 579-602. DOI: https://doi.org/10.18267/j.polek.614.

ZDRAŽIL, P, HÝBLOVÁ, A. 2013: Vliv př́mých zahraničních investic na ekonomickou výkonnost regionu In. Šilhánková, V., Maštálka, M. eds. Obyvatelstvo, region a bezpečnost. Regionální rozvoj mezi teorií a praxí. Sborník př́spěvku. Pardubice: Univerzita Pardubice, 129-137. ISBN 978-80-7395-724-7

Článek vznikl v rámci projektu č. TB040MPO010 Limity pro investice v ČR, program Beta Technologická agentura České republiky.

\section{Adresa autora}

Ing. Milan Damborský, PhD.

Ústav regionálního rozvoje

Fakulta regionálního rozvoje a mezinárodních vztahů, Mendelova Univerzita v Brne

Zemědělská 1665/1, 61300 Brno, Česká republika

milan.damborsky@mendelu.cz 